\title{
Global chemical transport model study of ozone response to changes in chemical kinetics and biogenic volatile organic compounds emissions due to increasing temperatures: Sensitivities to isoprene nitrate chemistry and grid resolution
}

\begin{abstract}
Akinori Ito, ${ }^{1}$ Sanford Sillman, ${ }^{2}$ and Joyce E. Penner ${ }^{2}$
Received 6 October 2008; revised 13 January 2009; accepted 24 February 2009; published 1 May 2009.

[1] Global modeling studies show a wide variability in the response of the $\mathrm{O}_{3}$ budget to climate change as projected by applying Intergovernmental Panel on Climate Change scenarios in climate models. We employ sensitivity studies to elucidate the major uncertainties in the response of tropospheric $\mathrm{O}_{3}$ to perturbations in biogenic volatile organic compounds (BVOC) emissions and reaction rate coefficients due to changes in temperature. The change in global $\mathrm{O}_{3}$ burden due to an increase in BVOC emissions associated with $\mathrm{a}+5 \mathrm{~K}$ depends critically on the assumed treatment for the fraction of $\mathrm{NO}_{\mathrm{x}}$ recycled $(0-100 \%)$ from isoprene nitrate $(+9$ to $+34 \mathrm{Tg})$, in contrast to the chemical reaction rate coefficients response $\left(-8\right.$ to $-9 \mathrm{Tg}$ ). The model $\mathrm{O}_{3}$ burden shows sensitivity $(40 \mathrm{Tg})$ to the $\mathrm{NO}_{\mathrm{x}}$ recycling efficiencies $(0-100 \%)$ similar to the burden's sensitivity to the grid resolution $\left(4^{\circ} \times 5^{\circ}-1^{\circ} \times 1^{\circ}\right)$. The correlation of $\mathrm{O}_{3}$ with total alkyl nitrates ( $\Sigma$ ANs) in the surface air at a California forest site shows sensitivity to the $\mathrm{NO}_{\mathrm{x}}$ recycling $(40-100 \%)$ similar to the correlation's sensitivity to the horizontal resolution $\left(4^{\circ} \times 5^{\circ}-1^{\circ}\right.$ $\times 1^{\circ}$ ). The results of the sensitivity simulations imply that the slope of $\mathrm{O}_{3}$ to $\Sigma$ ANs might be used to constrain the yield of isoprene nitrate and $\mathrm{NO}_{\mathrm{x}}$ recycling fraction, but better agreement could be achieved by using a higher-resolution model with even higher $\mathrm{NO}_{\mathrm{x}}$ recycling from isoprene nitrate. Our results suggest that the reduction of $\mathrm{NO}_{\mathrm{x}}$ recycling from isoprene nitrate be set apart from that due to the effect of the grid resolution in the chemical transport model.
\end{abstract}

Citation: Ito, A., S. Sillman, and J. E. Penner (2009), Global chemical transport model study of ozone response to changes in chemical kinetics and biogenic volatile organic compounds emissions due to increasing temperatures: Sensitivities to isoprene nitrate chemistry and grid resolution, J. Geophys. Res., 114, D09301, doi:10.1029/2008JD011254.

\section{Introduction}

[2] A number of global modeling studies have suggested that projected climate changes over the next century will result in a decrease in the overall global tropospheric burden of ozone $\left(\mathrm{O}_{3}\right)$ because of the increased destruction of $\mathrm{O}_{3}$ associated with increased water vapor [e.g., Brasseur et al., 1998; Johnson et al., 1999; Stevenson et al., 2000; Dentener et al., 2006a]. Stevenson et al. [2006] have intercompared a total of 26 different global atmospheric chemistry models. Simulations for the assessment included the influence of climate change from 2000 and 2030 with global annual mean surface temperatures of between 0.31 and $0.95 \mathrm{~K}$ projected by applying Intergovernmental Panel on Climate Change (IPCC) scenarios in climate models. The models show a wide variability in the response of the global

\footnotetext{
${ }^{1}$ Frontier Research Center for Global Change, Japan Agency for Marine-Earth Science and Technology (JAMSTEC), Yokohama, Japan.

${ }^{2}$ Department of Atmospheric, Oceanic, and Space Sciences, University of Michigan, Ann Arbor, Michigan, USA.
}

Copyright 2009 by the American Geophysical Union. 0148-0227/09/2008JD011254 tropospheric $\mathrm{O}_{3}$ budget when a climate change scenario is considered. These differences highlight significant imperfections in our current understanding of the key factors involved (e.g., deep tropical convection, stratospheretroposphere exchange, and water vapor response).

[3] Several 3-D chemical transport model (CTM) sensitivity studies have been performed to elucidate the major uncertainties in the response of $\mathrm{O}_{3}$ to climate change. Wild [2007] and $W u$ et al. [2007] have demonstrated that the magnitudes of the emissions of nitrogen oxides $\left(\mathrm{NO}_{\mathrm{x}}=\right.$ $\mathrm{NO}+\mathrm{NO}_{2}$ ) from lightning and of isoprene emissions from vegetation contribute to major uncertainties in model calculations of $\mathrm{O}_{3}$ production. Both of them recognized that the different isoprene chemistry schemes might be an important source of differences between model studies. Our 3-D model study follows these comprehensive studies and aims to elucidate the role of the organic hydroxynitrates ( $\mathrm{RONO}_{2}$, "isoprene nitrates") from biogenic volatile organic compounds (BVOC) emissions in the response of $\mathrm{O}_{3}$ to temperature increases.

[4] There has been increasing attention paid to the climate change penalty of an increase in surface $\mathrm{O}_{3}$ mixing ratios 
near polluted areas. However, regional and global model studies have shown that there are significant uncertainties in the response of surface $\mathrm{O}_{3}$ to temperature increases, especially over the southeastern United States [Hogrefe et al., 2004; Murazaki and Hess, 2006; Dawson et al., 2007; Tagaris et al., 2007; Racherla and Adams, 2008; Wu et al., 2008; Zhang et al., 2008]. Dawson et al. [2007] used the CBM-IV chemical mechanism [Gery et al., 1989] and showed that a uniform increase of surface temperature by $2.5 \mathrm{~K}$ would result in $0-4 \mathrm{ppb}$ increases of the summertime daily maximum 8-h average $\mathrm{O}_{3}$. Hogrefe et al. [2004] used the CBM-IV chemical mechanism and found the average daily maximum $8-\mathrm{h} \mathrm{O}_{3}$ increase of 4-8 ppb during summertime in the 2050 s relative to the 1990 s using the IPCC SRES A2 scenario (1.5-3.5 K). Zhang et al. [2008] reported a lower $\mathrm{O}_{3}$ increase of $1-5 \mathrm{ppb}$ using the IPCC A1B scenario (2-4.6 K). Racherla and Adams [2008] used $100 \% \mathrm{NO}_{\mathrm{x}}$ recycling with a $12 \%$ yield of isoprene nitrate [Horowitz et al., 1998] and predicted a 5 ppb increase in the 95th percentile $\mathrm{O}_{3}$ in response to the $1.4-\mathrm{K}$ increase in the surface temperatures projected using the IPCC SRES A2 scenario. Murazaki and Hess [2006] used 100\% $\mathrm{NO}_{\mathrm{x}}$ recycling with an $8 \%$ yield [Horowitz et al., 2003] without considering changes in BVOC emissions and reported a smaller average $\mathrm{O}_{3}$ increase of $1-2 \mathrm{ppb}$ during summertime between 1991 and 1999 and 2091-2099 using the IPCC A1B scenario $(2-3.5 \mathrm{~K})$ than the $3-9$ ppb range reported by Racherla and Adams [2006]. On the other hand, Tagaris et al. [2007] and Wu et al. [2008] found little effect. Wu et al. [2008] speculated that different treatments of isoprene nitrate chemistry could be a major source of the difference in the model responses of the $\mathrm{O}_{3}$ to temperature increase. However, Tagaris et al. [2007] used the SAPRC mechanism [Carter, 2000], in which the $\mathrm{NO}_{\mathrm{x}}$ recycling is larger than that in the CBM-IV. Thus the attribution of the differences in the projected $\mathrm{O}_{3}$ changes to one single factor is often disturbed by multiple competing effects such as the model inputs (e.g., emissions, land cover, and boundary conditions), the BVOC emission models used, the treatments of various atmospheric meteorological and chemical processes in global versus regional models and the horizontal grid resolutions used in the simulations.

[5] There is notable uncertainty in present-day estimates of BVOC emissions. Guenther et al. [2006] developed an emissions model to estimate the range of global isoprene emissions. They found that their estimates ranged from 440 to $660 \mathrm{TgC} \mathrm{a}^{-1}$ and were strongly dependent on the driving variables, which included land cover (leaf area index and plant functional type distributions) and weather (solar radiation, air temperature, humidity, wind speed, and soil moisture) conditions. A wide range of biogenic emissions for isoprene has been used in different chemistry transport models (220-630 TgC a ${ }^{-1}$ [Stevenson et al., 2006]). The lowest value for isoprene emissions was used for the IPCC Third Assessment Report (TAR) [Prather et al., 2003], while significantly higher emissions were used for the Fourth Assessment Report (AR4). There is an ongoing debate about the convergence toward a common estimate of global isoprene emissions [Arneth et al., 2008; Lelieveld et al., 2008].

[6] Accurate future predictions of isoprene emissions are also uncertain, because the response of terrestrial ecosys- tems to human activities and climate change is highly complex. Predicted estimates of global isoprene emissions range from 640 to $890 \mathrm{TgC} \mathrm{a}^{-1}$ at the end of the $21 \mathrm{st}$ century [Sanderson et al., 2003; Lathière et al., 2005; Wiedinmyer et al., 2006], with the biggest driver being the projected increase in surface temperature. Guenther et al. [2006] estimated that isoprene emissions may increase by more than a factor of 2 using temperature distributions simulated by applying IPCC A1 scenarios in global climate models for the year 2100. In addition to the temperature changes, the long-term prediction of isoprene emissions is sensitive to land-use change [Lathière et al., 2006; Ito et al., 2008], $\mathrm{CO}_{2}$ concentration [Rosenstiel et al., 2003; Arneth et al., 2007], and water availability [Pegoraro et al., 2005; Müller et al., 2008].

[7] The spatial and temporal changes of surface $\mathrm{O}_{3}$ in response to an increase of isoprene emissions due to increased surface temperatures are strongly influenced by background $\mathrm{NO}_{\mathrm{x}}$ levels [e.g., Sanderson et al., 2003; Hauglustaine et al., 2005; Brasseur et al., 2006; Wiedinmyer et al., 2006; Tao et al., 2007; Kunkel et al., 2008; Zeng et al., 2008]. In a comprehensive modeling study, Sillman and Samson [1995] described how the partitioning of total reactive nitrogen $\left(\mathrm{NO}_{\mathrm{y}}\right)$ into total peroxy nitrates $(\Sigma \mathrm{PNs})$, total alkyl nitrates ( $\Sigma \mathrm{ANs})$, and $\mathrm{HNO}_{3}$ is expected to vary as a function of temperature. From their study of polluted rural environments, they concluded that $\mathrm{O}_{3}$ mixing ratios increase with temperature because of an increase in the thermal decomposition rate for $\Sigma$ PNs, making $\Sigma$ ANs the dominant contributors to $\mathrm{NO}_{z}$ $\left(=\mathrm{NO}_{\mathrm{y}}-\mathrm{NO}_{\mathrm{x}}\right)$ at higher temperatures rather than $\mathrm{HNO}_{3}$. Their model result was consistent with observations at a rural site in the southeastern United States [Olszyna et al., 1997]. On the other hand, Day et al. [2008], who observed atmospheric reactive nitrogen compounds at a California forest site, argued that there was a larger increase in the contribution of $\mathrm{HNO}_{3}$ to $\mathrm{NO}_{\mathrm{z}}$ with temperature and a smaller increase in the contribution of $\Sigma$ ANs to $\mathrm{NO}_{\mathrm{z}}$ than that calculated by Sillman and Samson [1995]. They attributed the inconsistency between the model and observation to a steep increase in the hydroxyl radical $(\mathrm{OH})$ inferred from the observations of temperature trends in the $\mathrm{HNO}_{3} /$ $\mathrm{NO}_{2}$ ratio. These observed changes in reactive nitrogen compounds versus temperature provide a good basis for evaluating the ability of models to predict temperaturedependent responses. The temperature-dependent response of $\mathrm{NO}_{\mathrm{y}}$ partitioning is especially important for assessments of future $\mathrm{O}_{3}$, because the fate of $\mathrm{NO}_{x}$ significantly affects $\mathrm{O}_{3}$ formation in the global atmosphere. Thus it is meaningful to compare the sensitivity of relatively long lived $\mathrm{NO}_{\mathrm{x}}$ reaction products $\left(\Sigma \mathrm{PNs}, \Sigma \mathrm{ANs}\right.$ and $\left.\mathrm{HNO}_{3}\right)$ in a CTM to temperature changes with those observed.

[8] Previous box and 3-D model studies on regional and global scales have demonstrated that $\mathrm{O}_{3}$ mixing ratios and reactive nitrogen partitioning are sensitive to uncertainties in the chemical oxidation pathways of isoprene [e.g., Horowitz et al., 1998, 2007; Pöschl et al., 2000; von Kuhlmann et al., 2004; Fiore et al., 2005; Ito et al., 2007a]. Fiore et al. [2005] showed that the modeled response of $\mathrm{O}_{3}$ over the eastern United States to changes in isoprene emissions depends on the fate of isoprene nitrates. The reaction of isoprene nitrates with $\mathrm{OH}$ and $\mathrm{O}_{3}$ 
can lead to the net production of $\mathrm{NO}_{\mathrm{x}}$ (recycling) in the remote atmosphere or to the loss of $\mathrm{NO}_{\mathrm{x}}$ in isoprene-rich air if there are significant yields of secondary multifunctional organic nitrates [Giacopelli et al., 2005]. In an extreme case, when the recycling of $\mathrm{NO}_{\mathrm{x}}$ was changed from $0 \%$ to $100 \%$, surface $\mathrm{O}_{3}$ mixing ratios increased by approximately $20 \%$ at almost all locations [Ito et al., 2007a], which was comparable to the difference between different chemical mechanisms considered in the box model intercomparison by Pöschl et al. [2000].

[9] Day et al. [2003] found that the $\Sigma$ ANs is strongly correlated with $\mathrm{O}_{3}$ with a slope of $80 \mathrm{O}_{3}$ per $\Sigma A N s$ (ppb/ ppb) at UC-BFRS. Horowitz et al. [2007] used measurements from the ICARTT field campaign [Fehsenfeld et al., 2006; Singh et al., 2006] to infer the yield of isoprene nitrate and the $\mathrm{NO}_{\mathrm{x}}$ recycling fraction, based in part on the model versus measured slope (82 observed, 81 simulated with $40 \% \mathrm{NO}_{\mathrm{x}}$ recycling and a $4 \%$ yield of isoprene nitrate). Recently, Paulot et al. [2009] found a higher yield (12\%) and recycling efficiency of $55 \%$ on the basis of an analysis using atmospheric smog chamber experiments. Perring et al. [2009] suggested much higher recycling efficiencies for different yields $(67 \%$ isoprene nitrates recycling for $12 \%$ yield; $97 \%$ for $4.4 \%$ ) on the basis of an observed correlation between $\Sigma$ ANs and $\mathrm{HCHO}$. We investigate the sensitivity of $\mathrm{O}_{3}$ per $\Sigma$ ANs for different $\mathrm{NO}_{\mathrm{x}}$ recycling fractions to understand why the $\mathrm{NO}_{\mathrm{x}}$ recycling fraction obtained by the model calibration is lower than that obtained by Paulot et al. [2009].

[10] In addition to the effects of the treatment of isoprene chemistry, the production of $\mathrm{O}_{3}$ over isoprene-emitting regions near polluted areas is influenced by the model resolution, owing to artificial mixing of air masses of different origins when near surface emissions are added to coarse grids [e.g., Sillman et al., 1990; Liang and Jacobson, 2000; Fiore et al., 2003; Wild and Prather, 2006; Wild, 2007]. Sillman et al. [1990] calculated more $\mathrm{O}_{3}$ production in the boundary layer and less $\mathrm{NO}_{\mathrm{z}}$ export to the free troposphere (FT) at lower resolution, because dilution of precursor $\mathrm{NO}_{\mathrm{x}}$ emissions in a coarse model grid increased the $\mathrm{O}_{3}$ production efficiency, defined as the number of $\mathrm{O}_{3}$ molecules produced per unit $\mathrm{NO}_{\mathrm{x}}$ oxidized [Liu et al., 1987]. Fiore et al. [2003] compared the GEOS-Chem model with regional model simulations (horizontal resolution of 36 $\mathrm{km}^{2}$ ) and showed that the $4^{\circ} \times 5^{\circ}$ resolution captured the large-scale features of the surface $\mathrm{O}_{3}$ distribution, although the ability to capture local $\mathrm{O}_{3}$ maxima was compromised.

[11] The purpose of this paper is to investigate the processes that could have a major impact on $\mathrm{O}_{3}$ mixing ratios when temperatures change. We focus on the link between the treatment of isoprene nitrates and the horizontal resolution in the model and on the evaluation of the model predictability of temperature-dependent responses of $\mathrm{O}_{3}$ and the relatively long lived reactive nitrogen compounds. For this purpose, a global CTM is used to calculate the $\mathrm{O}_{3}$ mixing ratios. We investigate a sensitivity study, in which we prescribe the water vapor concentration in the model and only perturb the effects of temperature on chemical reaction rates and BVOC emissions. We also examine the correlation between $\mathrm{O}_{3}$ and temperature and between reactive nitrogen species and temperature in the day-to-day record as predicted by the CTM and in comparison with observations over an isoprene-emitting region (reported by Day et al. [2008]). These day-to-day correlations with temperature can reflect the influence of a wide variety of meteorological factors (solar radiation, humidity, mixed layer depth, and transport patterns), which coincidentally vary with temperature, rather than the effect of temperature in isolation. Dayto-day correlations with temperature also may not reflect the combined changes in meteorology and emissions associated with future climate. Nonetheless, they provide a test of the ability of models to predict changes in chemically reactive species in response to temperature against ambient conditions. Section 3 describes the different scenarios examined. Section 4 examines the sensitivity of the global $\mathrm{O}_{3}$ budget and surface mixing ratios in different simulations as well as comparisons of the model with observations of $\mathrm{O}_{3}$ and other intermediate species. Section 5 presents a summary of our findings.

\section{Model Approach}

[12] For this study, we use the Integrated Massively Parallel Atmospheric Chemical Transport (IMPACT) model driven by assimilated meteorological fields which are obtained from the Goddard Earth Observation System (GEOS) of the NASA Global Modeling and Assimilation Office (GMAO) [Schubert et al., 1993]. The GEOS-3 meteorological data set [Zhu et al., 2003] for the year 2001 is suitable for the comparison with the observations by Day et al. [2008]. IMPACT was originally developed at the Lawrence Livermore National Laboratory (LLNL) [Rotman et al., 2004] but was extended to treat aerosols and detailed chemical reactions for a wider set of VOC at the University of Michigan [Liu et al., 2005; Feng and Penner, 2007; Ito et al., 2007a]. The GEOS-3 meteorological fields were provided with a 6 -h temporal resolution on a horizontal resolution of $1^{\circ} \times 1^{\circ}$ with 48 vertical layers. Since the gas-phase model does not communicate with the aerosol model interactively, two separate simulations were performed for a 1-year time period with a 6-month spin-up period for the gas-phase model and a 2-month spin-up for the aerosol model.

[13] A number of revisions to the chemistry described by Ito et al. [2007a] were made for the present study. We adopt the production of secondary multifunctional organic nitrates (XNITR) from the oxidation of isoprene and terpene nitrates by the three main oxidants, $\mathrm{OH}, \mathrm{O}_{3}$, and $\mathrm{NO}_{3}$ in the work of Horowitz et al. [2007] to the previous IMPACT mechanism of Ito et al. [2007a]. Our yield of isoprene nitrate from the reaction of isoprene peroxy radicals with $\mathrm{NO}$ which ranges from $8 \%$ for $593 \mathrm{hPa}$ to $12 \%$ for $1000 \mathrm{hPa}$ [Sprengnether et al., 2002] is larger than the 4\% yield [Chen et al., 1998] in the base simulation of Horowitz et al. [2007]. This chemistry reaction mechanism assumes that the reaction of isoprene nitrate with $\mathrm{OH}$ and $\mathrm{O}_{3}$ yields

$$
\mathrm{A} \times\left(\mathrm{GLYC}+\mathrm{NO}_{2}\right)+\mathrm{B} \times(\mathrm{XNITR})+\left(\mathrm{HO}_{2}\right)
$$

where GLYC represents hydroxyacetaldehyde, sum of A and $B$ equals 1 , and $A$ takes on the values $0,0.4$, and 1 . We changed the production of hydroxyacetone in the assumption by Paulson and Seinfeld [1992] to GLYC, on the basis of the model comparison with observations of Ito et al. 
Table 1. Global Emissions of $\mathrm{O}_{3}$ Precursors Except Biogenic Volatile Organic Compounds for the Year 2001 ${ }^{\mathrm{a}}$

\begin{tabular}{|c|c|}
\hline Species & Emission Rate \\
\hline $\mathrm{NO}_{\mathrm{x}}$ & 46 \\
\hline $\mathrm{CO}$ & 1232 \\
\hline Methylethyl ketone & 8.6 \\
\hline $\mathrm{C}_{2} \mathrm{H}_{6}$ & 9.0 \\
\hline $\mathrm{C}_{3} \mathrm{H}_{8}$ & 4.5 \\
\hline $\mathrm{CH}_{3} \mathrm{CHO}$ & 6.0 \\
\hline $\mathrm{HCHO}$ & 6.1 \\
\hline C4-C5 alkanes (ALK4) & 15.9 \\
\hline$\geq$ C6 alkanes (ALK7) & 10.3 \\
\hline Ethene & 14.4 \\
\hline Propene & 18.9 \\
\hline Trans-2-butene & 5.1 \\
\hline Benzene & 7.2 \\
\hline Toluene & 10.0 \\
\hline m-xylene & 9.1 \\
\hline Acetone & 4.4 \\
\hline Methanol & 11.1 \\
\hline Formic acid & 2.4 \\
\hline Acetic acid & 14.7 \\
\hline Phenol & 12.5 \\
\hline
\end{tabular}

[2007a]. Species scavenging depends on solubility through the Henry's law coefficient, as described by Rotman et al. [2004]. The Henry's law constant of $1.7 \times 10^{4} \mathrm{M} \mathrm{atm}^{-1}$ for isoprene nitrate [O'Sullivan et al., 1996] is of the same order of magnitude as that of $8.3 \times 10^{4} \mathrm{M} \mathrm{atm}^{-1}$ for $\mathrm{HNO}_{3}$ [Schwartz and White, 1981]. XNITR is removed by wet and dry deposition at the same rates as isoprene nitrate, as its further reactions are assumed to convert it to more highly substituted organic nitrates that do not recycle $\mathrm{NO}_{\mathrm{x}}$ back into the atmosphere. We include methanol deposition following Jacob et al. [2005]. The water vapor in the troposphere is prescribed by the meteorological data. The tropopause height is defined as the lowest level at which a synthetic $\mathrm{O}_{3}$ tracer from the stratosphere is greater than $150 \mathrm{ppbv}$ [McLinden et al., 2000]. Reaction rates are taken from the recent IUPAC [Atkinson et al., 2004] and JPL [Sander et al., 2006] assessments. The aerosols used in the calculation of the uptake of $\mathrm{N}_{2} \mathrm{O}_{5}$ are calculated using the model described by Feng and Penner [2007]. We apply the same monthly averaged $\mathrm{NO}_{\mathrm{x}}$ emission rates and the $\mathrm{HO}_{\mathrm{x}}\left(=\mathrm{OH}+\mathrm{HO}_{2}\right)$ and $\mathrm{O}_{3}$ output from an initial gas-phase run with the previously fixed aerosol concentrations for the reaction of $\mathrm{N}_{2} \mathrm{O}_{5}$ on aerosols in the aerosol simulation. We use the aerosol emissions of Dentener et al. [2006b]. The uptake rates of $\mathrm{N}_{2} \mathrm{O}_{5}, \mathrm{HO}_{2}, \mathrm{NO}_{2}$ and $\mathrm{NO}_{3}$ by aerosols are calculated from the aerosol simulation driven by the 2001 meteorological fields at $2^{\circ} \times 2.5^{\circ}$ resolution.

[14] The emissions inventory has been recompiled to represent the year 2001 for the comparison with the measurements by Day et al. [2008]. Table 1 lists the global emissions of $\mathrm{O}_{3}$ precursors except BVOC used in the present work. Isoprene emissions are based on a modified version of the inventory of Guenther et al. [1995] by Wang et al. [1998] and Bey et al. [2001]. Monoterpene emissions are based on the work of Guenther et al. [1995] as modified by Wang et al. [1998]. The BVOC emissions are calculated interactively with the same meteorological data. We run the model for 1 year and calculate the monthly emissions. Then, we scale the monthly emissions to normalize to a global biogenic isoprene source of $500 \mathrm{TgC} \mathrm{a}^{-1}$ and terpene sources of $130 \mathrm{TgC} \mathrm{a}^{-1}$ as in the work of Guenther et al. [1995] for all scenarios at the base case temperature. The other temperature-dependent BVOC emissions for ethene, propene, acetone, and methanol are distributed according to emissions of isoprene [Ito et al., 2007a]. We use the surface air temperature dependency from Guenther et al. [1999] following Palmer et al. [2006] to determine the resulting change in emissions. This functional dependence exponentially increases BVOC emissions with increasing surface air temperature up to a maximum that is dependent on the average temperature during the past 15 days. Lightning $\mathrm{NO}_{\mathrm{x}}$ emissions are based on the convective mass fluxes from the meteorological fields at each resolution [Allen and Pickering, 2002]. The vertical distribution of the source is based on observed profiles [Pickering et al., 1998]. We normalized the total emissions to $3 \mathrm{TgN} \mathrm{a}^{-1}$ as per Bey et al. [2001]. The soil $\mathrm{NO}_{\mathrm{x}}$ emissions are obtained from Yan et al. [2005] for the year 2001. Anthropogenic fossil fuel emissions are taken from M. G. Schultz et al. (RETRO emission data sets and methodologies for estimating emissions, project report, 2007, available at http://retro.enes.org/ reports/D1-6_final.pdf) for 2000 except for aircraft $\mathrm{NO}_{\mathrm{x}}$ emissions, which are from the monthly mean emission inventory for 1999 of Mortlock and Van Alstyne [1998] and Sutkus et al. [2001]. The global biomass burning emissions are updated to those of Ito et al. [2007b], which are based on the emissions developed by Ito and Penner [2005] for the year 2000 and scaled to the year 2001 using the TOMS AI data [Herman et al., 1997]. The MODIS fire product [Giglio et al., 2006] is used to produce the seasonal variations in open biomass burning emissions except in southern Africa, where regional emissions from open vegetation burning are available [Ito et al., 2007c].

\section{Chemical Transport Model Sensitivity Studies}

[15] The different simulations performed in this study are summarized in Table 2. To assess the effects of increases in temperature on the chemical composition of the atmosphere, we consider the change in both the reaction rate coefficients (section 3.1) that depend on temperature and the BVOC emissions (section 3.2) to perturbations of temperature throughout the troposphere. A fixed uniform change of temperature is useful to investigate each of these parameters separately so that the effects of each as well as the synergy can be determined. This would help identify the major factors that could have an effect on air quality as temperature changes. To assess the uncertainties in the model response, we examine the sensitivity of $\mathrm{O}_{3}$, its precursors, and its production to the treatment of the recycling of $\mathrm{NO}_{\mathrm{x}}$ from isoprene nitrates (section 3.3) and to the model resolution (section 3.4).

\subsection{Effects of Temperature on Chemistry}

[16] The effects of temperature on oxidant photochemistry are examined by applying globally uniform changes in temperature $( \pm 5 \mathrm{~K})$ to the chemical reaction rate coefficients only after Wild [2007]. Increased temperatures affect chemical reaction kinetics and thus $\mathrm{O}_{3}$ production and loss rates. The reactions responsible for this temperature effect are mainly associated with the chemistry of peroxyalkyl nitrates 
Table 2. Summary of Different Simulations Performed in This Study

\begin{tabular}{|c|c|c|c|c|}
\hline Simulation & Run Name & Isoprene Emission & $\begin{array}{c}\mathrm{NO}_{\mathrm{x}} \text { Recycling, } \\
\%\end{array}$ & Resolution \\
\hline 1 & $\mathrm{~L}^{\mathrm{a}}{ }_{0} 0$ & 500 & 0 & $4^{\circ} \times 5^{\circ}$ \\
\hline 2 & $\mathrm{~L} \overline{4} 0$ & 500 & 40 & $4^{\circ} \times 5^{\circ}$ \\
\hline 3 & $\mathrm{~L}_{-} 100$ & 500 & 100 & $4^{\circ} \times 5^{\circ}$ \\
\hline 4 & $\mathrm{~L}_{-}{ }_{0} \mathrm{P}^{\mathrm{b}} \mathrm{E}^{\mathrm{c}}$ & 940 & 0 & $4^{\circ} \times 5^{\circ}$ \\
\hline 5 & $\mathrm{~L}_{-}^{-}{ }_{-}^{-} \mathrm{M}^{\mathrm{d}} \mathrm{E}$ & 270 & 0 & $4^{\circ} \times 5^{\circ}$ \\
\hline 6 & $\mathrm{~L}_{-}^{-} 4 \overline{0} \_\mathrm{PE}$ & 940 & 40 & $4^{\circ} \times 5^{\circ}$ \\
\hline 7 & $\mathrm{~L}$ 40_ME & 270 & 40 & $4^{\circ} \times 5^{\circ}$ \\
\hline 8 & L_100_PE & 940 & 100 & $4^{\circ} \times 5^{\circ}$ \\
\hline 9 & $\mathrm{~L}-100 \_\mathrm{ME}$ & 270 & 100 & $4^{\circ} \times 5^{\circ}$ \\
\hline 10 & $\overline{\mathrm{L}} \_0 \_\overline{\mathrm{P}} \mathrm{C}^{\mathrm{e}}$ & 500 & 0 & $4^{\circ} \times 5^{\circ}$ \\
\hline 12 & $\mathrm{~L} 0 \mathrm{C} \mathrm{MC}$ & 500 & 0 & $4^{\circ} \times 5^{\circ}$ \\
\hline 13 & L_40_PC & 500 & 40 & $4^{\circ} \times 5^{\circ}$ \\
\hline 13 & $\mathrm{~L}^{-} 40-\mathrm{MC}$ & 500 & 40 & $4^{\circ} \times 5^{\circ}$ \\
\hline 14 & L_100_PC & 500 & 100 & $4^{\circ} \times 5^{\circ}$ \\
\hline 15 & $\mathrm{~L}^{-} 100-\mathrm{MC}$ & 500 & 100 & $4^{\circ} \times 5^{\circ}$ \\
\hline 16 & $\bar{L}-0 \_\overline{P E C} C^{f}$ & 940 & 0 & $4^{\circ} \times 5^{\circ}$ \\
\hline 17 & L_0_MEC & 270 & 0 & $4^{\circ} \times 5^{\circ}$ \\
\hline 18 & L_40_PEC & 940 & 40 & $4^{\circ} \times 5^{\circ}$ \\
\hline 18 & L_40_MEC & 270 & 40 & $4^{\circ} \times 5^{\circ}$ \\
\hline 19 & $\mathrm{~L}^{-} 10 \overline{\mathrm{PEC}}$ & 940 & 100 & $4^{\circ} \times 5^{\circ}$ \\
\hline 20 & L_100_MEC & 270 & 100 & $4^{\circ} \times 5^{\circ}$ \\
\hline 21 & $\mathrm{M}^{\mathrm{g}^{-}} 40$ & 500 & 40 & $2^{\circ} \times 2.5^{\circ}$ \\
\hline 22 & $\mathrm{H}^{\mathrm{h}^{-}} 40$ & 500 & 40 & $1^{\circ} \times 1^{\circ}$ \\
\hline 23 & $\mathrm{H}^{\mathrm{h}}-100$ & 500 & 100 & $1^{\circ} \times 1^{\circ}$ \\
\hline
\end{tabular}

${ }^{a}$ Low resolution $\left(4^{\circ} \times 5^{\circ}\right)$

${ }^{\mathrm{b}}$ Temperature increase $(+5 \mathrm{~K})$ applied to chemical reaction rate coefficients and/or biogenic volatile organic compound (BVOC) emissions.

${ }^{\mathrm{c}} \mathrm{BVOC}$ emission perturbation.

${ }^{\mathrm{d}}$ Temperature decrease $(-5 \mathrm{~K})$ applied to chemical reaction rate coefficients and/or BVOC emissions.

${ }^{\mathrm{e}} \mathrm{Chemical}$ reaction rate coefficient perturbation.

${ }^{\mathrm{f}} \mathrm{BVOC}$ emission and chemical reaction rate coefficient perturbations.

${ }^{\mathrm{g}}$ Middle resolution $\left(2^{\circ} \times 2.5^{\circ}\right)$

${ }^{\mathrm{h}}$ High resolution $\left(1^{\circ} \times 1^{\circ}\right)$.

such as peroxyacetyl nitrate $\left(\mathrm{PAN}, \mathrm{CH}_{3} \mathrm{C}(\mathrm{O}) \mathrm{O}_{2} \mathrm{NO}_{2}\right)$, because thermal decomposition is the main loss reaction for these compounds [Carter et al., 1979]. Although we focus on the sensitivity of $\mathrm{O}_{3}$ in this paper, we note that the sensitivity of $\mathrm{CH}_{4}$ oxidation to temperature has also been shown to have temperature dependence relevant for chemistry-climate links [Johnson et al., 1999; Fiore et al., 2006].

\subsection{Effects of Temperature on Emissions}

[17] The effects of temperature on BVOC emissions are examined by applying a perturbation based on changes in temperature $( \pm 5 \mathrm{~K})$ to the calculation of BVOC emission rates. The BVOC whose emission is sensitive to temperature include isoprene, ethene, propene, terpenes, acetone, and methanol. Our estimates of isoprene emission range from $270(-5 \mathrm{~K})$ to $940 \mathrm{TgC} \mathrm{a}^{-1}(+5 \mathrm{~K})$. In section 4.1.3, we discuss the implications of the findings from recent studies by Arneth et al. [2007] and Heald et al. [2009].

\subsection{Effects of $\mathrm{NO}_{\mathbf{x}}$ Recycling From Isoprene Nitrates}

[18] The response of $\mathrm{O}_{3}$ to a change in temperatures is sensitive to the $\mathrm{NO}_{\mathrm{x}}$ recycling rate from the oxidation products of biogenic emissions, which are related to the temperature. The treatment of the recycling of $\mathrm{NO}_{\mathrm{x}}$ when isoprene nitrates and nitrates from the oxidation of terpene react with $\mathrm{OH}$ and $\mathrm{O}_{3}$ is varied from $0 \%$ to $40 \%$ to $100 \%$ following Horowitz et al. [2007].

\subsection{Effects of Model Resolution}

[19] The response of $\mathrm{O}_{3}$ to the $\mathrm{NO}_{\mathrm{x}}$ recycling rate is influenced by the model resolution when biogenic emissions are mixed with anthropogenic sources within the same coarse grids. We examine the sensitivity of $\mathrm{O}_{3}$, its precursors, and its production to horizontal resolution by running the model at three different horizontal resolutions: low resolution $\left(4^{\circ} \times 5^{\circ}\right)$, middle $\left(2^{\circ} \times 2.5^{\circ}\right)$, and high $\left(1^{\circ} \times\right.$ $\left.1^{\circ}\right)$. The middle and high resolutions used here may be comparable with those used by Wild and Prather [2006] at $\mathrm{T} 42\left(2.8^{\circ} \times 2.8^{\circ}\right)$ and $\mathrm{T} 106\left(1.1^{\circ} \times 1.1^{\circ}\right)$ resolution for March and April 2001.

\section{Model Results and Discussion}

\subsection{Global Ozone Budget}

[20] The results of the sensitivity studies for the lowresolution simulations (numbers $1-20$ ) listed in Table 2 are shown in Figure 1. In the analysis of the global $\mathrm{O}_{3}$ budget, " $\mathrm{O}_{3}$ " represents " $\mathrm{O}_{3}+\mathrm{NO}_{2}+2 \times \mathrm{NO}_{3}+\mathrm{PAN}+\mathrm{MPAN}+$ $\mathrm{HNO}_{4}+\mathrm{HNO}_{3}+3 \times \mathrm{N}_{2} \mathrm{O}_{5}+$ npan." The lifetime of $\mathrm{O}_{3}$ is determined from its chemical removal and deposition rates. In sections 4.1.1 and 4.1.2, we investigate each of these parameters separately. In section 4.1.3, we examine the combined effect of these parameters. In section 4.1.4, we explore the sensitivity to model resolution.

\subsubsection{Sensitivities to BVOC Emissions and $\mathrm{NO}_{\mathrm{x}}$ Recycling}

[21] The response of the calculated $\mathrm{O}_{3}$ budget to the perturbation of BVOC emissions due to temperature changes is sensitive to the treatment of the recycling of $\mathrm{NO}_{\mathrm{x}}$. Increased recycling of $\mathrm{NO}_{\mathrm{x}}$ from isoprene nitrates provides a direct increase in the model mixing ratios of both $\mathrm{NO}_{\mathrm{x}}$ and organics (which are also recycled), which lead to increased $\mathrm{O}_{3}$ formation and thus its burden from $330 \mathrm{Tg}$ for (L_0) to $370 \mathrm{Tg}$ for (L_100). Higher $\mathrm{NO}_{\mathrm{x}}$ recycling could transport more $\mathrm{NO}_{\mathrm{x}}$ to remote regions than lower recycling, because the former does not remove $\mathrm{NO}_{\mathrm{x}}$ efficiently over isoprene-emitting regions (see section 4.2 for further discussion).

[22] Stevenson et al. [2006] showed the large spread in $\mathrm{O}_{3}$ burden (274-407 $\mathrm{Tg}$ ) among 25 atmospheric models, although it is not clear how many previous studies have included the isoprene nitrate chemistry. Wild [2007] did not include isoprene nitrates in the simplified hydrocarbon oxidation scheme and showed that differences in isoprene emissions (220-630 $\mathrm{TgC} \mathrm{a}^{-1}$ ) might account for $20 \mathrm{Tg}$ in $\mathrm{O}_{3}$ burden. Wu et al. [2008] used $0 \% \mathrm{NO}_{\mathrm{x}}$ recycling with the yield of Sprengnether et al. [2002] and showed little changes in $\mathrm{O}_{3}$ burden $(315-319 \mathrm{Tg})$ by varying the isoprene emissions $\left(0-400 \mathrm{TgC} \mathrm{a}{ }^{-1}\right)$. The effect of increased isoprene emissions from 270 to $940 \mathrm{TgC} \mathrm{a}^{-1}$ on the increase in $\mathrm{O}_{3}$ burden depends critically on the assumed treatment for the fraction of $\mathrm{NO}_{\mathrm{x}}$ recycled and ranges from $17 \mathrm{Tg}$ for (L_0_PE) - (L_0_ME) to $57 \mathrm{Tg}$ for (L_100_PE) - (L_100_ME). This interrelationship can be explained by the synergy between additional BVOC and increased ambient $\mathrm{NO}_{\mathrm{x}}$ associated with recycling [McKeen et al., 1991; Tao et al., 2003]. As BVOC emissions are increased, ambient $\mathrm{NO}_{\mathrm{x}}$ in biogenic source regions is increased with increasing $\mathrm{NO}_{\mathrm{x}}$ recycling owing to the increase of the organic nitrates except XNITR. The increase 


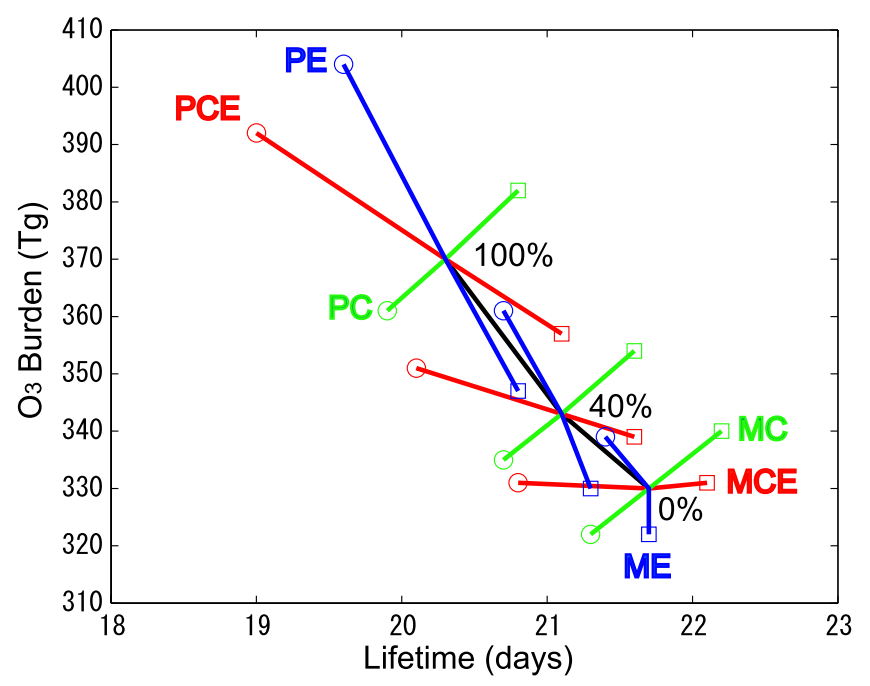

Figure 1. The relationship between the tropospheric burden of $\mathrm{O}_{3}$ and its lifetime from chemical removal and deposition from the results of the sensitivity studies listed in Table 2. The black line represents the sensitivity to the assumed recycling of $\mathrm{NO}_{\mathrm{x}}$ from isoprene nitrates. The red lines denote the sensitivity to changes in both chemical reaction rate coefficients and emissions from changes in temperature. The blue lines indicate the sensitivity to changes in emissions from changes in temperature. The green lines show the sensitivity to changes in chemical reaction rate coefficients from changes in temperature. The circles represent results for a temperature increase $(+5 \mathrm{~K})$ applied to the chemistry and/or emissions. The squares represent results for a temperature decrease $(-5 \mathrm{~K})$ applied to the chemistry and/or emissions. PC and $\mathrm{MC}$ represent temperature increase $(+5 \mathrm{~K})$ and decrease $(-5 \mathrm{~K})$, respectively, applied to chemical reaction rate coefficients. $\mathrm{PE}$ and $\mathrm{ME}$ represent temperature increase $(+5 \mathrm{~K})$ and decrease $(-5 \mathrm{~K})$, respectively, applied to emissions. PCE and MCE represent temperature increase $(+5 \mathrm{~K})$ and decrease $(-5 \mathrm{~K})$, respectively, applied to chemical reaction rate coefficients and emissions.

in $\mathrm{O}_{3}$ is driven largely by the increased role of PAN as a transporter of $\mathrm{NO}_{\mathrm{x}}$ and the rerelease of $\mathrm{NO}_{\mathrm{x}}$ from isoprene nitrates is determined by the recycling fraction of $\mathrm{NO}_{\mathrm{x}}$. This increases the transport of $\mathrm{NO}_{\mathrm{x}}$ to the remote troposphere [e.g., Singh et al., 1998, 2000], which increases the overall net production of $\mathrm{O}_{3}$ because $\mathrm{O}_{3}$ production in the remote troposphere is more efficient [e.g., Liu et al., 1987].

[23] The slope of the lifetime versus $\mathrm{O}_{3}$ burden due to the effect of a temperature increase on the BVOC emissions is smaller when the recycling of $\mathrm{NO}_{\mathrm{x}}$ is lower. The steeper slope represents a higher chemical production of $\mathrm{O}_{3}$. Increases in BVOC emissions lead to increased net chemical $\mathrm{O}_{3}$ production for $\left(\mathrm{L} \_40 \_\mathrm{PE}\right)-\left(\mathrm{L} \_40\right)\left(17 \mathrm{Tg} \mathrm{a}^{-1}\right)$ and $\left(\mathrm{L} \_100 \_\mathrm{PE}\right)-\left(\mathrm{L} \_100\right)\left(58 \overline{\mathrm{Tg} \mathrm{a}}{ }^{-1}\right)$ recycling of $\mathrm{NO}_{\mathrm{x}}$ but decreased net production for $\left(\mathrm{L}_{-}{ }_{-} \mathrm{PE}\right)-\left(\mathrm{L}_{-} 0\right)$ $\left(-2 \mathrm{Tg} \mathrm{a}^{-1}\right)$. The slope for the low recycling of $\mathrm{NO}_{\mathrm{x}} \overline{\mathrm{d}}$ ue to the effects of a decrease in temperature of $-5 \mathrm{~K}$ on emissions is steeper than that owing to an increase of $+5 \mathrm{~K}$. $W u$ et al. [2007] found that net chemical $\mathrm{O}_{3}$ production became saturated for nonmethane volatile organic com- pounds (NMVOC) emissions in the range of 200 and 500 $\left(\mathrm{Tg} \mathrm{C} \mathrm{a}{ }^{-1}\right)$. This is consistent with our results. A further increase in the BVOC emissions to $940\left(\mathrm{Tg} \mathrm{C} \mathrm{a}^{-1}\right)$ changes the sign of the net chemical production. These results indicate that a lower recycling fraction for $\mathrm{NO}_{\mathrm{x}}$ introduces a larger chemical loss rate for $\mathrm{O}_{3}$ for the effect of a temperature increase of $5 \mathrm{~K}$ on BVOC emissions. However, the $\mathrm{O}_{3}$ burden $\left(17 \mathrm{Tg} \mathrm{O}_{3}\right)$ is increased for $(\mathrm{L} 0 \mathrm{PE})-$ (L_0_ME), mainly because the wet deposition of $\mathrm{HNO}_{3}$ $\left(-13 \mathrm{Tg} \mathrm{O}_{3} \mathrm{a}^{-1}\right)$ is decreased.

\subsubsection{Sensitivity to Chemical Reaction Rate Change due to Temperature Increases}

[24] The effect of changes in chemical reaction rates due to increased temperatures by $5 \mathrm{~K}$ causes slight decreases $(-8$ to $-9 \mathrm{Tg})$ in the total tropospheric $\mathrm{O}_{3}$ burden in our model. Previously, Sillman and Samson [1995] suggested that total tropospheric $\mathrm{O}_{3}$ would decrease in this case because precursors are processed and removed more rapidly in polluted regions, where the $\mathrm{O}_{3}$ production efficiency per $\mathrm{NO}_{\mathrm{x}}$ molecule is lower. Wild [2007] showed that the tropospheric burden of $\mathrm{O}_{3}$ dropped by less than $1 \%$ for a temperature rise of $5 \mathrm{~K}$ on oxidant photochemistry. Most of the decreases in $\mathrm{O}_{3}$ are seen in the FT (global averaged differences for (L_40_PC) - (L_40) are -1.1 ppb in FT versus $-0.5 \mathrm{ppb}$ in surface air) and remote sites where $\mathrm{NO}_{\mathrm{x}}$ from the decomposition of PAN affects $\mathrm{O}_{3}$ owing to the higher $\mathrm{O}_{3}$ production efficiency per unit $\mathrm{NO}_{x}$ (OPE) in these regions. On the other hand, the effect of increased temperatures on chemistry leads to increased $\mathrm{O}_{3}$ in source regions (see section 4.2).

[25] Here, we find that the change in the $\mathrm{O}_{3}$ burden due to the change in reaction rate coefficients associated with a temperature change is largely independent from the assumed $\mathrm{NO}_{\mathrm{x}}$ recycling fraction, in contrast to the BVOC emission response. Gross chemical $\mathrm{O}_{3}$ production decreases $\left(-13.6 \mathrm{Tg} \mathrm{a}^{-1}\right)$ for $\left(\mathrm{L} \_40 \_\mathrm{PC}\right)-\left(\mathrm{L} \_40\right)$ in response to reduced $\mathrm{NO}_{\mathrm{x}}$ (the global averaged differences are $-1.8 \mathrm{ppt}$ in the FT versus +1.6 ppt in surface air) resulting from less efficient transport by PAN (as suggested by Singh et al. $[1998,2000])$. The decrease in chemical $\mathrm{O}_{3}$ production $\left(-23.4 \mathrm{Tg} \mathrm{a}^{-1}\right)$ for $(\mathrm{L} 100 \mathrm{PC})-(\mathrm{L} 100)$ is larger than that $\left(-6.7 \mathrm{Tg} \mathrm{a}^{-1}\right)$ for $\left(\mathrm{L}_{-} \overline{0}_{-} \mathrm{PC}\right)-\left(\overline{\mathrm{L}}_{-} 0\right)$ in response to larger decrease in $\mathrm{NO}_{\mathrm{x}}$ (the global averaged differences in the FT are $-2.4 \mathrm{ppt}$ for (L_100_PC) - (L_100) versus - $1.4 \mathrm{ppt}$ for (L_0_PC) - (L_0)). However, this is counterbalanced by larger decrease in total loss $\left(-23.5 \mathrm{Tg} \mathrm{a}^{-1}\right)$ for $\left(\mathrm{L}_{-}\right.$100_PC) - (L_100) than that $\left(-6.5 \mathrm{Tg} \mathrm{a}^{-1}\right)$ for $\left(\mathrm{L}_{-}{ }_{0} \mathrm{PC}\right)-\left(\mathrm{L}_{-} 0\right)$, which is reflected in larger decrease in the chemical loss via the reaction of $\mathrm{O}_{3}$ with $\mathrm{OH}$ and photochemical destruction (the global averaged differences in the FT are $-1.3 \mathrm{ppb}$ for (L_100_PC) - (L_100) versus $-0.98 \mathrm{ppb}$ for $\left.\left(\mathrm{L} \_0 \_\mathrm{PC}\right)-\left(\mathrm{L} \_0\right)\right)$.

\subsubsection{Sensitivity to Combined Simulations}

[26] The effect of changes in chemical reaction rates due to increased temperatures $(+5 \mathrm{~K})$ causes slight decreases in the total tropospheric $\mathrm{O}_{3}$ burden $(-8$ to $-9 \mathrm{Tg})$. Increased emissions of BVOC $(+5 \mathrm{~K})$, however, lead to increases in $\mathrm{O}_{3}$ burden ( +9 to $\left.+34 \mathrm{Tg}\right)$ and this effect is larger than the net decrease in global $\mathrm{O}_{3}$ burden. Overall, global mean $\mathrm{O}_{3}$ increases with temperature $(+5 \mathrm{~K})$, ranging from $1 \mathrm{Tg}$ for $0 \% \mathrm{NO}_{\mathrm{x}}$ recycling to $22 \mathrm{Tg}$ for $100 \%$. 
(a) Isoprene

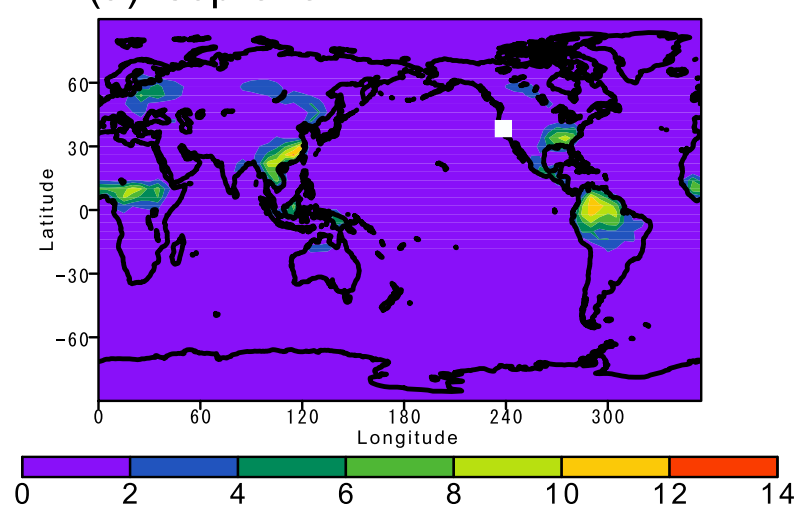

(b) PAN

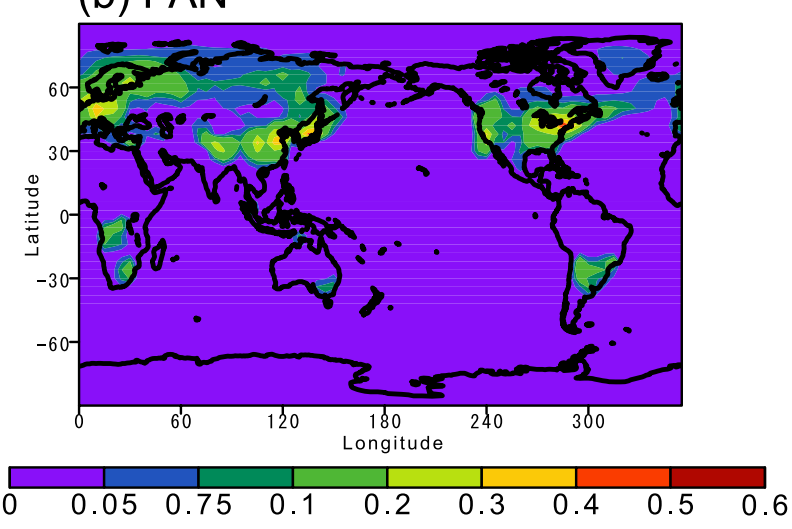

(c) Nitrogen Oxides

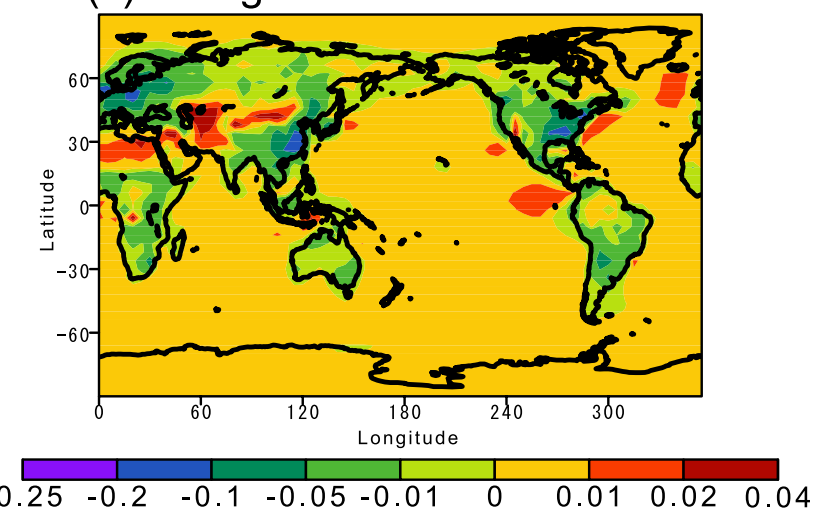

Figure 2. The changes in mixing ratios (ppbv) for (a) isoprene, (b) peroxyacetyl nitrate (PAN), and (c) $\mathrm{NO}_{\mathrm{x}}$, for the difference between the case with increased emissions caused by a $5-\mathrm{K}$ increase in temperature and the base case, (L_40_PE) - (L_40), in the surface air in July. The white box in Figure $2 \mathrm{a}$ shows the location of the University of California-Blodgett Forest Research Station (UC-BFRS).

[27] Arneth et al. [2007] found that the increase in isoprene emissions induced by temperature and vegetation changes in the next century would be offset when the inhibition of leaf isoprene emissions by increasing atmospheric $\mathrm{CO}_{2}$ concentration is accounted for in their model. In this case which maintains the isoprene emissions within $\pm 15 \%$ of present values, the response of $\mathrm{O}_{3}$ to temperature increase would be insensitive to the uncertainties in the $\mathrm{NO}_{\mathrm{x}}$ recycling rate, because the response of the $\mathrm{O}_{3}$ burden to the change in reaction rate coefficients associated with a temperature change is largely independent from the assumed $\mathrm{NO}_{\mathrm{x}}$ recycling fraction. Recently, Heald et al. [2009] found that future isoprene emissions increased by more than a factor of 2 in 2100 (to $1242 \mathrm{TgC} \mathrm{a}^{-1}$ ) owing to temperature and vegetation changes even when the effect of $\mathrm{CO}_{2}$ inhibition is included. In this case, the response of $\mathrm{O}_{3}$ to future climate would be sensitive to the uncertainties in the $\mathrm{NO}_{\mathrm{x}}$ recycling rate, because the increase in global $\mathrm{O}_{3}$ burden due to an increase in BVOC emissions depends critically on the fraction of $\mathrm{NO}_{\mathrm{x}}$ recycled from isoprene nitrate. The divergence of the future predictions of isoprene emissions highlights the need for further study of the effects of changes in isoprene emissions in the future climate.

\subsubsection{Sensitivity to Model Resolution}

[28] Model results at the low resolution $\left(4^{\circ} \times 5^{\circ}\right)$ which use lower recycling fractions for $\mathrm{NO}_{\mathrm{x}}$ (between $0 \%$ and $40 \%$ ) compare better with the tropospheric $\mathrm{O}_{3}$ burden of $335 \pm 10 \mathrm{Tg}$ determined by Wild [2007] from available $\mathrm{O}_{3}$ climatologies. However, the global mean $\mathrm{O}_{3}$ burden for 2001 is $13 \%$ smaller at the high resolution (302 $\mathrm{Tg}$ ) than at the low with the $40 \% \mathrm{NO}_{\mathrm{x}}$ recycling fraction $(340 \mathrm{Tg})$, reflecting less net chemical $\mathrm{O}_{3}$ production at the higher resolution. This amount is comparable to the difference in $\mathrm{O}_{3}$ burden between $0 \%$ and $100 \% \mathrm{NO}_{\mathrm{x}}$ recycling of isoprene nitrates $(40 \mathrm{Tg})$. The global mean $\mathrm{O}_{3}$ burden during March and April decreases by $3.0 \%$ as the resolution decreases from $2^{\circ} \times 2.5^{\circ}$ to $1^{\circ} \times 1^{\circ}$, which is comparable to the decrease $(-3.2 \%)$ from a resolution change from T42 to T106 calculated by Wild and Prather [2006]. On the basis of the tendency calculated using the low-resolution model, the burden is expected to be increased by $8 \%$ when $100 \%$ recycling of $\mathrm{NO}_{\mathrm{x}}$ is assumed rather than $40 \%$. These results suggest that the assumptions of lower BVOC emissions and lower $\mathrm{NO}_{\mathrm{x}}$ recycling fractions are not needed for higherresolution simulation to match the burden of $\mathrm{O}_{3}$ derived by Wild [2007].

\subsection{Changes in Surface $\mathrm{O}_{3}$ and Its Precursors due to Increases in Temperature}

[29] The sensitivity of surface $\mathrm{O}_{3}$ and its precursors to changes in BVOC emissions (section 4.2.1) and chemical reaction rates (section 4.2.2) due to increases in temperature are analyzed here for July. In section 4.2.3, we examine the combined effect of these parameters. In section 4.2.4, we investigate the $\mathrm{NO}_{\mathrm{x}}$ recycling fraction associated with model resolution.

\subsubsection{Sensitivity to BVOC Emissions}

[30] The geographical distribution of the changes in isoprene mixing ratios (ppbv) for (L_40_PE) - (L_40) is shown in Figure $2 \mathrm{a}$. Enhancements of more than $2 \mathrm{ppbv}$ are found over the main isoprene-emitting regions in the temperate and boreal forests. In the tropical forests, the changes reach more than 8 ppbv. The largest changes in tropical forest regions occur because of a large decrease in $\mathrm{OH}$ and increase in the photochemical lifetime of isoprene [e.g., Houweling et al., 1998; Guenther et al., 1999]. However, Lelieveld et al. [2008] proposed that BVOC oxidation recycles $\mathrm{OH}$ efficiently $(40-80 \%)$ at low- $\mathrm{NO}_{\mathrm{x}}$ mixing ratios through reactions of $\mathrm{HO}_{2}$ with organic peroxy radicals $\left(\mathrm{RO}_{2}\right)$, on the basis of the aircraft measurements of $\mathrm{OH}$ and related species in unpolluted air over the Amazon 
rain forest, laboratory measurements, and numerical modeling. Subsequently, Butler et al. [2008] demonstrated that a recycling of $\mathrm{OH}$ of $40-50 \%$ was needed to match the model results with the observations, although the resulting high$\mathrm{OH}$ concentrations lead to unrealistically low mixing ratios of isoprene. In section 4.3.2.4, the isoprene mixing ratios and $\mathrm{OH}$ concentrations from the model results are compared to the observations.

[31] The changes in the PAN mixing ratios (ppbv) are shown for (L_40_PE) - (L_40) in Figure 2b. Increases in the surface $\mathrm{PA} N \overline{\mathrm{N}}$ mixing ratios are calculated over polluted regions $(0.1-0.5 \mathrm{ppbv})$, reflecting increases in the organic compounds available for the PAN formation.

[32] The change in the $\mathrm{NO}_{\mathrm{x}}$ mixing ratio (ppbv) is shown for (L_40_PE) - (L_40) in Figure 2c. Decreases of the surface $\mathrm{NO}_{\mathrm{x}}$ mixing ratios $(-0.05-0.2 \mathrm{ppbv})$ are calculated over both the isoprene- and $\mathrm{NO}_{\mathrm{x}}$-emitting regions for the case when $40 \%$ recycling fraction for $\mathrm{NO}_{\mathrm{x}}$ is assumed. Increases (0.01-0.04 ppbv) are found over remote locations where nitrogen-containing compounds can be transported from the source regions [e.g., Sanderson et al., 2003; Hauglustaine et al., 2005; Wiedinmyer et al., 2006; Zeng et al., 2008]. Increased $\mathrm{NO}_{\mathrm{x}}$ is especially noteworthy in the desert and semidesert regions of central Asia and the western United States. In each of these regions there is an apparent release of $\mathrm{NO}_{\mathrm{x}}$ imported from neighboring regions that have high emissions of both anthropogenic $\mathrm{NO}_{\mathrm{x}}$ and BVOC. These increases in $\mathrm{NO}_{\mathrm{x}}$ occur even with the assumed $40 \%$ recycling fraction for $\mathrm{NO}_{\mathrm{x}}$. Over the same regions, smaller $\mathrm{NO}_{\mathrm{x}}$ increases (up to $0.03 \mathrm{ppbv}$ ) occur in the cases with $0 \% \mathrm{NO}_{\mathrm{x}}$ recycling, while larger $\mathrm{NO}_{\mathrm{x}}$ increases (up to $0.09 \mathrm{ppbv}$ ) occur in the cases with $100 \% \mathrm{NO}_{\mathrm{x}}$ recycling.

[33] The resulting changes in surface $\mathrm{O}_{3}$ mixing ratios due to the effect of $\mathrm{a}+5-\mathrm{K}$ increase in temperature on emissions are shown for the 0,40 , and $100 \%$ recycling fractions for $\mathrm{NO}_{\mathrm{x}}$ in Figures $3 \mathrm{a}-3 \mathrm{c}$. The $\mathrm{O}_{3}$ changes due to the effects of $+5 \mathrm{~K}$ on emissions are larger than those due to $-5 \mathrm{~K}$ (the global averaged differences are $1.3 \mathrm{ppb}$ for (L_40_PE) - (L_40) versus - $1.1 \mathrm{ppb}$ for (L_40_ME) $\left(\mathrm{L}_{-} 40 \overline{)}\right)$, because the responses of $\mathrm{O}_{3}$ to the temperature changes are subject to the effect of nonlinearities in the BVOC emissions which increase exponentially with increasing surface air temperature.

[34] Decreases in surface $\mathrm{O}_{3}$ (up to $-4.5 \mathrm{ppbv}$ ) are found over tropical forests because more isoprene directly reacts with $\mathrm{O}_{3}$ to increase its loss and more isoprene nitrates act as a sink of $\mathrm{NO}_{\mathrm{x}}$ to decrease its production. Under low- $\mathrm{NO}_{\mathrm{x}}$ conditions, where $\mathrm{O}_{3}$ formation is sensitive to the level of $\mathrm{NO}_{\mathrm{x}}$, more $\mathrm{NO}_{\mathrm{x}}$ is removed as isoprene nitrates for increased emissions of isoprene as well as other BVOC and more is scavenged as XNITR in the case with a lower recycling fraction for $\mathrm{NO}_{\mathrm{x}}$. The largest increases in surface $\mathrm{O}_{3}$ (up to $11.4 \mathrm{ppbv}$ ) are found near or downwind from polluted areas. These increases occur in two types of locations: (1) source regions in which $\mathrm{O}_{3}$ formation is likely to be sensitive to VOC emissions, such as over north China and northern Europe, and (2) downwind locations that have increased $\mathrm{NO}_{\mathrm{x}}$ (Figure 2c) over the Middle East and central Asia [e.g., Li et al., 2001; Lelieveld et al., 2002; Wild et al., 2004]. Our model results suggest that additional measurements for the downwind regions would be helpful in

\section{(a) $0 \%$}

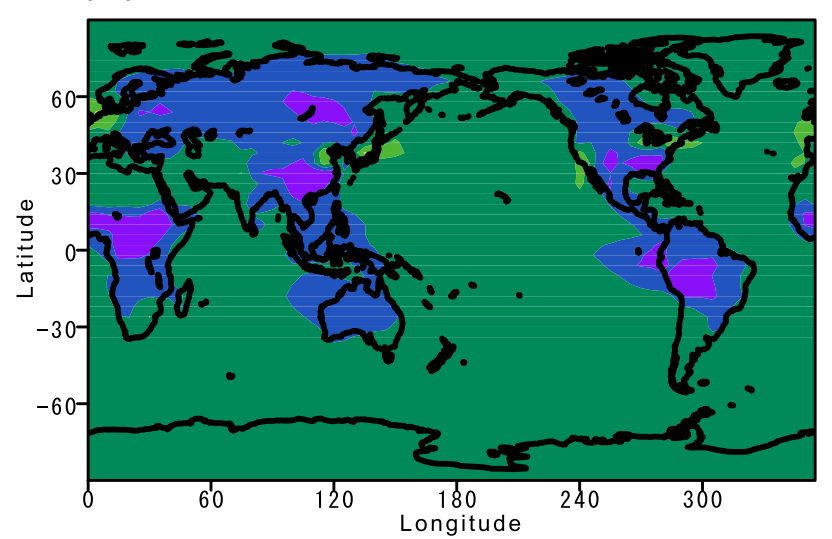

(b) $40 \%$

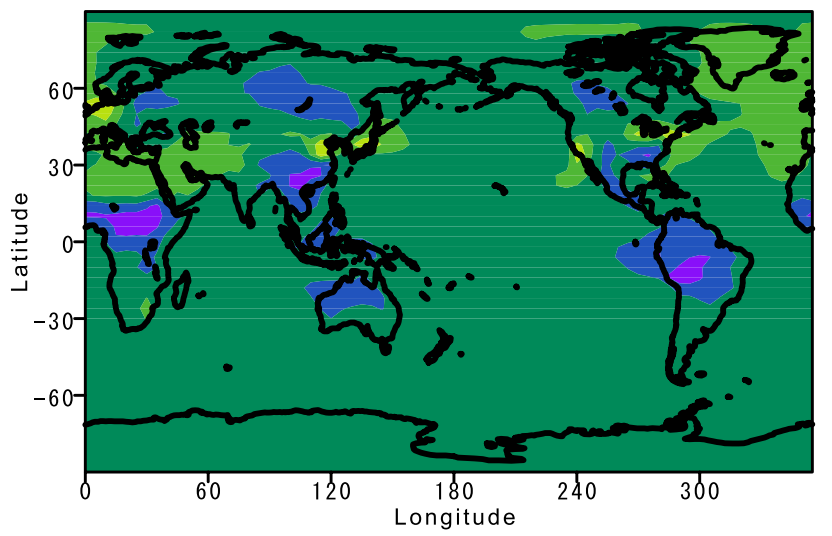

\section{(c) $100 \%$}

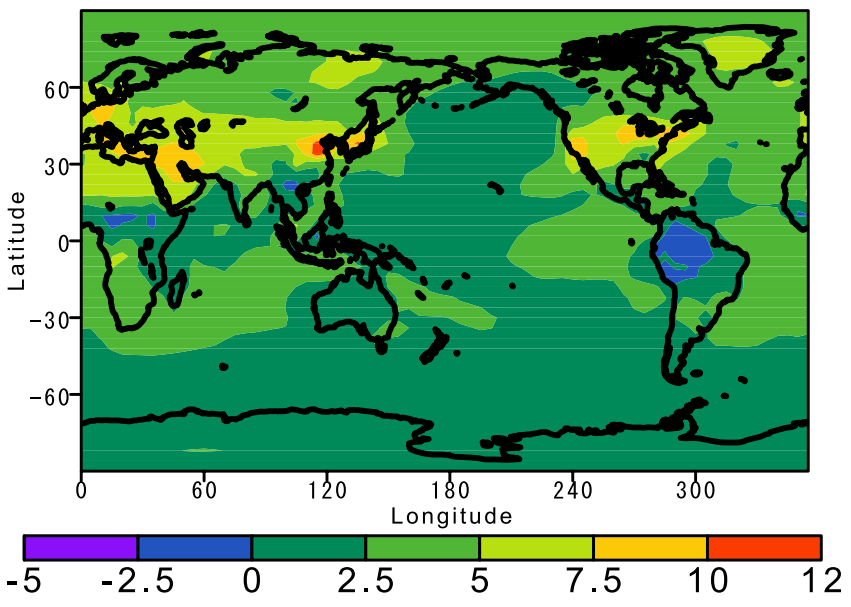

Figure 3. The changes in surface $\mathrm{O}_{3}$ mixing ratios (ppbv) in July due to the difference between the cases with increased emissions caused by a $5-\mathrm{K}$ increase in temperature (L_0_PE, L_40_PE, and L_100_PE) and the base cases ( $\mathrm{L}_{-} 0$, L_40, and $\mathrm{L}_{-} 100$ ) for the assumption of (a) $0 \%$ recycling of $\mathrm{NO}_{\mathrm{x}}$ from isoprene nitrates, (b) $40 \%$ recycling of $\mathrm{NO}_{\mathrm{x}}$ from isoprene nitrates, and (c) $100 \%$ recycling of $\mathrm{NO}_{\mathrm{x}}$ from isoprene nitrates.

providing constraints on the temperature response of $\mathrm{O}_{3}$ and the recycling fraction for $\mathrm{NO}_{\mathrm{x}}$.

[35] The response of $\mathrm{O}_{3}$ to the effect of increases in temperature on emissions shows that the changes in $\mathrm{O}_{3}$ 


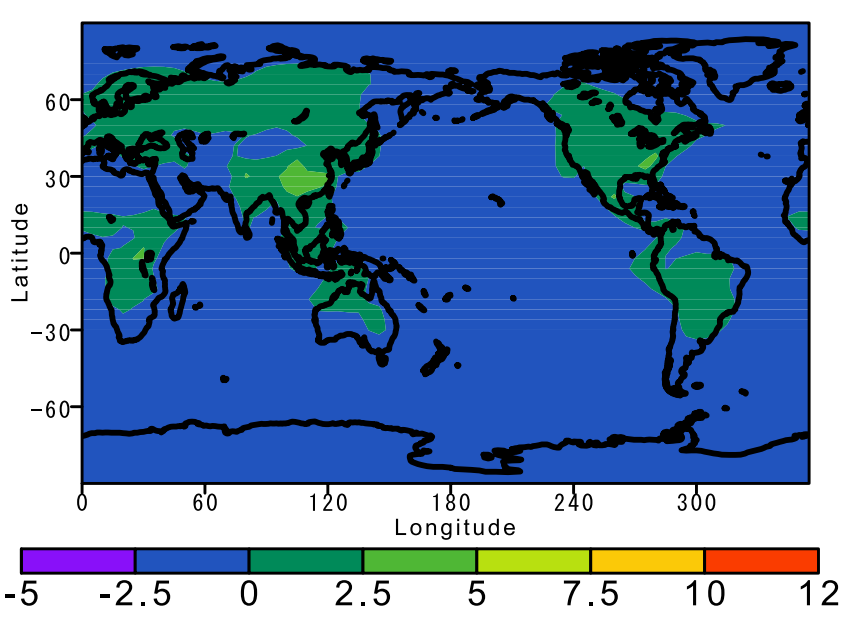

Figure 4. The change in surface $\mathrm{O}_{3}$ mixing ratios (ppbv) in July due to the effects of a $5-\mathrm{K}$ increase in temperature on the chemical reaction rate coefficients (L 40 PC) for the assumption of $40 \%$ recycling of $\mathrm{NO}_{\mathrm{x}}$ from isoprene nitrates.

are largely determined by the assumed recycling fraction for $\mathrm{NO}_{x}$. The $\mathrm{O}_{3}$ increase is larger in the case with higher recycling of $\mathrm{NO}_{\mathrm{x}}$. In the case with $0 \%$ recycling of $\mathrm{NO}_{\mathrm{x}}, \mathrm{O}_{3}$ mixing ratios mostly increase (up to $7.3 \mathrm{ppbv}$ ) over high$\mathrm{NO}_{\mathrm{x}}$ locations such as Germany, Beijing, Los Angeles, and the New York area. On the other hand, high BVOC emissions regions near polluted areas (e.g., the southeastern United States) result in a decrease in $\mathrm{O}_{3}$ (up to $-4.5 \mathrm{ppbv}$ ). This result indicates that the increased BVOC emissions near polluted areas efficiently remove $\mathrm{O}_{3}$ precursors in the case with lower recycling fractions for $\mathrm{NO}_{\mathrm{x}}$.

[36] Zhang et al. [2008] used CMAQ [Byun and Schere, 2006] with the CBM-IV chemical mechanism at the horizontal resolution of $36 \mathrm{~km}$ and found that the increase in BVOC emissions due to temperature increases caused a decrease in surface $\mathrm{O}_{3}$ by up to $1 \mathrm{ppb}$ over the southeastern United States. Their results are consistent with our results using a $0 \%$ recycling fraction for $\mathrm{NO}_{\mathrm{x}}$. The lumping approach used in the CBM-IV to reduce the complexity of the degradation schemes for higher hydrocarbons is different from that used in this work. A structural lumping, which groups species according to their bond type is used, as opposed to the molecular lumping approach used in this work, where groups of reactions of entire molecules are combined. Pöschl et al. [2000] and von Kuhlmann et al. [2004] have discussed the differences between these two approaches and attributed the major cause of differences to the approximate $50 \%$ loss of carbon in the initial reaction of isoprene with $\mathrm{OH}$ in the $\mathrm{CBM}$ scheme. Our results suggest that the more likely cause for the decrease in surface $\mathrm{O}_{3}$ is the implicit assumption of large losses of $\mathrm{NO}_{\mathrm{x}}$ in the CBM scheme, which lumps isoprene nitrate into one organic nitrate. The reaction of organic nitrate with $\mathrm{OH}$ in the CBM mechanism yields $\mathrm{HNO}_{3}$ and thus a $0 \%$ recycling fraction for $\mathrm{NO}_{\mathrm{x}}$.

\subsubsection{Sensitivity of Chemical Reaction Rates} to Temperature Increases

[37] The changes in surface $\mathrm{O}_{3}$ mixing ratios due to the effect of changes in chemical reaction rates associated with temperature increases are shown for the $40 \%$ recycling fraction for $\mathrm{NO}_{x}$ in Figure 4. Surface $\mathrm{O}_{3}$ increases (up to $4.2 \mathrm{ppbv}$ ) with increased temperature at most continental surface locations regardless of the assumed $\mathrm{NO}_{\mathrm{x}}$ recycling fraction. The response of $\mathrm{O}_{3}$ to temperature through changes in the chemical reaction rate coefficients occurs mainly because higher temperatures increase PAN decomposition, and the resulting release of $\mathrm{NO}_{\mathrm{x}}, \mathrm{HO}_{\mathrm{x}}$, and organics causes increased $\mathrm{O}_{3}$ formation [Carter et al., 1979]. Steiner et al. [2006] used CMAQ with SAPRC99 chemical mechanism at the horizontal resolution of $4 \mathrm{~km}$ and found the average afternoon $\mathrm{O}_{3}$ increase from 0 to $1 \mathrm{ppb}$ (rural) up to $2-4 \mathrm{ppb}$ (urban) owing to the effect of $2-3 \mathrm{~K}$ increase on chemical reaction rates during summertime. This may be comparable to our results over land areas $(0-2.5 \mathrm{ppbv})$ owing to the effect of a 5-K increase on a per-degree basis.

\subsubsection{Sensitivity to Combined Simulations}

[38] Large uncertainties have been found in the response of surface $\mathrm{O}_{3}$ over the southeastern United States, when the effects of climate change on isoprene emissions from the biosphere are considered in modeling experiments [e.g., Hogrefe et al., 2004; Tagaris et al., 2007; Racherla and Adams, 2008; Wu et al., 2008; Zhang et al., 2008]. Our results show decreases in $\mathrm{O}_{3}$ (down to $-2.5 \mathrm{ppbv}$ ) for a $0 \%$ $\mathrm{NO}_{\mathrm{x}}$ recycling fraction but increases in $\mathrm{O}_{3}$ (up to $10 \mathrm{ppbv}$ ) with a $100 \%$ recycling fraction and a uniform $5-\mathrm{K}$ increase in temperature over the southeastern United States (Figure 5).

[39] The rates of increase of $\mathrm{O}_{3}$ in polluted source regions due to chemistry and emissions are less than $10 \mathrm{ppbv}$ for $0 \%$ and $40 \% \mathrm{NO}_{\mathrm{x}}$ recycling fractions and are $10-14 \mathrm{ppbv}$ for a $100 \% \mathrm{NO}_{\mathrm{x}}$ recycling fraction, respectively (Figure 5). A similar analysis by Steiner et al. [2006] for the San Joaquin Valley in California found an average afternoon $\mathrm{O}_{3}$ increase of $0-2 \mathrm{ppb}$ in rural locations and 3-5 ppb near urban areas during summertime due to the effect of a $2-\mathrm{K}$ temperature increase on biogenic emissions alone. The SAPRC scheme used by Steiner et al. [2006] assigns isoprene nitrate into a lumped organic nitrate with a $65 \%$ recycling fraction for $\mathrm{NO}_{\mathrm{x}}$, and thus falls somewhere between our cases with $40 \%$ and $100 \%$ recycling. Although our results lack the sharp distinction between geographical regions shown by Steiner et al. [2006] (who used 4-km horizontal resolution in a regional simulation), our result for California is comparable on a per-degree basis.

\subsubsection{Sensitivity to Model Resolution and $\mathrm{NO}_{\mathrm{x}}$} Recycling Fraction

[40] The surface $\mathrm{O}_{3}$ mixing ratios for $\mathrm{H} \_100, \mathrm{~L} \_100$, and L_40 in July are compared to investigate the relationship between the change in $\mathrm{O}_{3}$ due to increases in the horizontal resolution and the change due to the $\mathrm{NO}_{\mathrm{x}}$ recycling fractions (Figure 6). The high-ozone region (54-63 ppb) for $\mathrm{L}_{-} 100$ is extended further from the source regions to east than that for H_100. Better agreement can be achieved by reducing the $\mathrm{NO}_{\mathrm{x}}$ recycling fraction, as shown in $\mathrm{L} 40$. This result illustrates that the treatment of isoprene nitrates as a loss for $\mathrm{NO}_{\mathrm{x}}$ in a coarse-resolution model compensates for the higher OPE that occurs in spreading $\mathrm{NO}_{\mathrm{x}}$ emissions over a larger box. Thus the lower $\mathrm{NO}_{\mathrm{x}}$ recycling fraction inferred in the study by Horowitz et al. [2007] than that deduced by Paulot et al. [2009] likely includes the effect of horizontal resolution in the model calibration. The lower recycling required at the coarse model grid is probably related to the conversion of $\mathrm{NO}_{2}$ to $\mathrm{HNO}_{3}$ in high-OH and low-VOC 


\section{(a) $0 \%$}

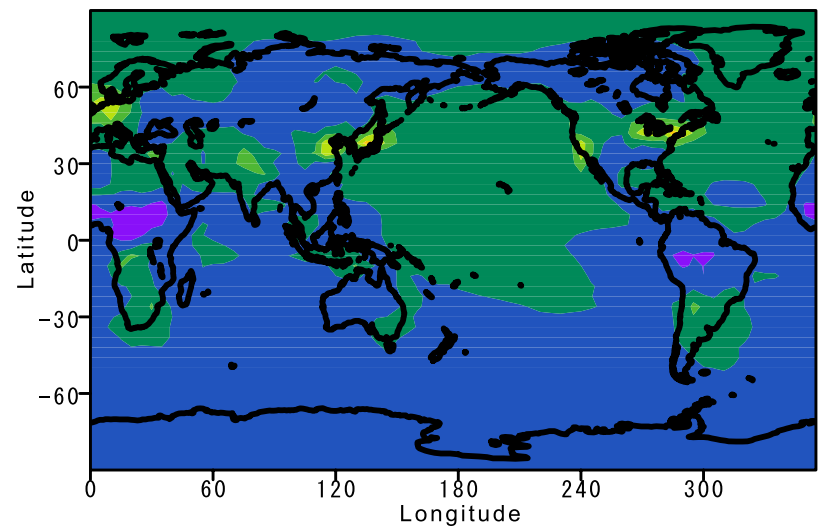

(b) $40 \%$

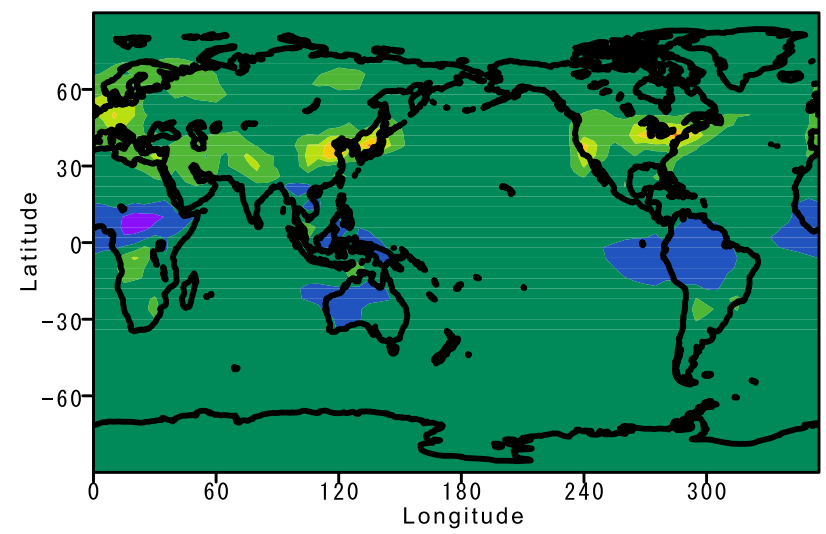

(c) $100 \%$

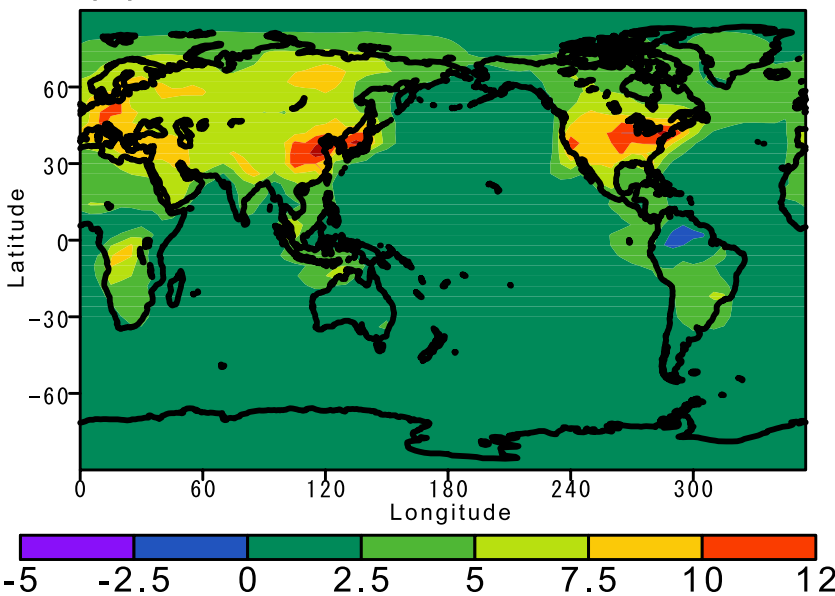

Figure 5. The change in surface $\mathrm{O}_{3}$ mixing ratios (ppbv) in July due to the effects of a $5-\mathrm{K}$ increase in temperature on the emission and chemical reaction rate coefficients for the assumption of (a) $0 \%$ recycling of $\mathrm{NO}_{\mathrm{x}}$ from isoprene nitrates, (b) $40 \%$ recycling of $\mathrm{NO}_{\mathrm{x}}$ from isoprene nitrates, and (c) $100 \%$ recycling of $\mathrm{NO}_{\mathrm{x}}$ from isoprene nitrates.

conditions because the artificial mixing of higher BVOC leads to more formation of $\Sigma$ ANs (more recycling of $\mathrm{NO}_{\mathrm{x}}$ and thus more production of $\mathrm{O}_{3}$ ) than actual partitioning into $\mathrm{HNO}_{3}$. In this case, the decrease of $\mathrm{NO}_{\mathrm{x}}$ availability for $\mathrm{O}_{3}$ production with temperature in rural areas should not be related to $\mathrm{BVOC}$ emissions in rural areas but to those in urban areas. The reasons for the specific model calibration should be elucidated before implementing it these calibrations in future predictions. In section 4.3.2.3, the correlation of $\mathrm{O}_{3}$ with $\Sigma$ ANs is compared between model results and observations.

\subsection{Comparison With Observations}

[41] The performance of the model in simulating the observed $\mathrm{O}_{3}$ and other intermediate species has been presented in earlier studies [Rotman et al., 2004; Ito et al.,
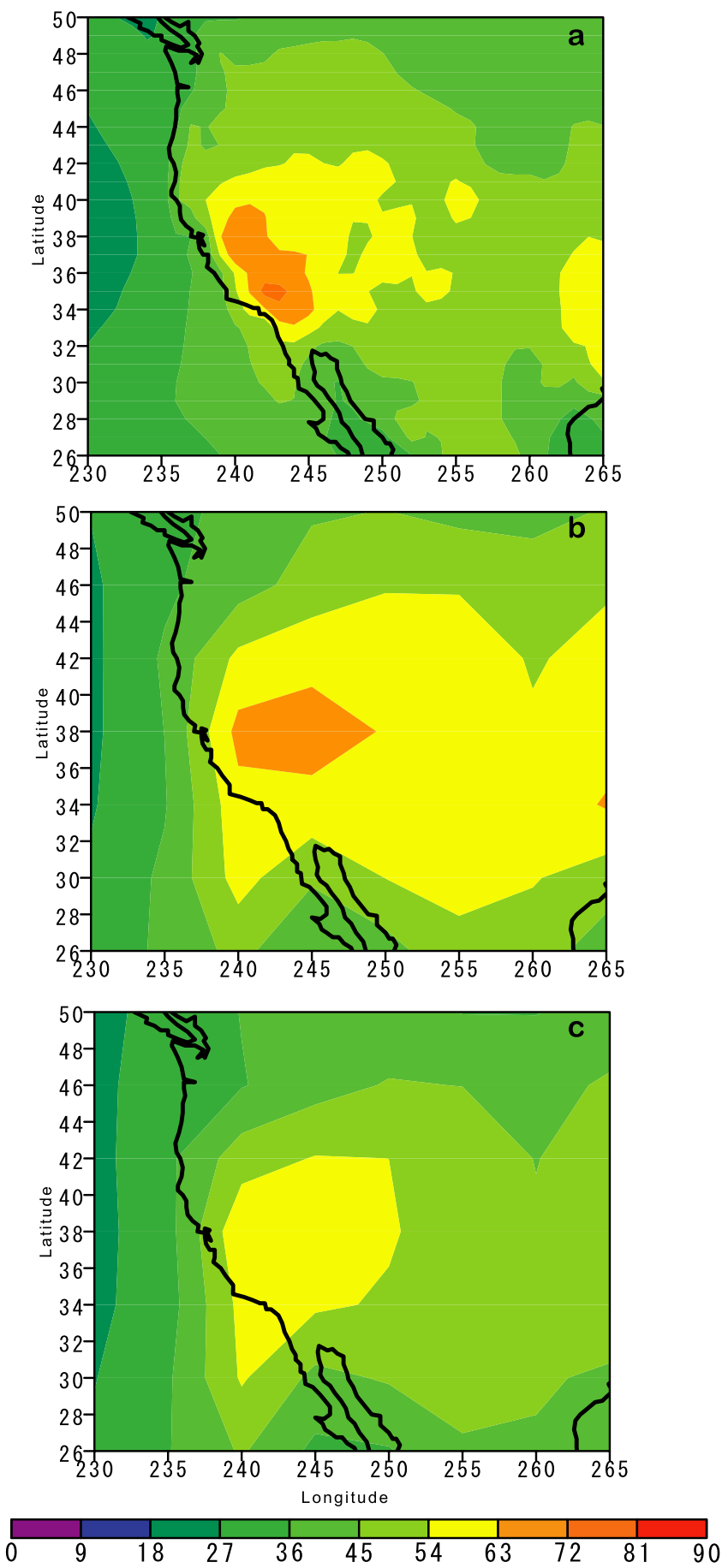

Figure 6. Ozone modeled surface mixing ratios (ppb) for (a) H_100, (b) L_100, and (c) L_40. All maps are monthly averages for July. 


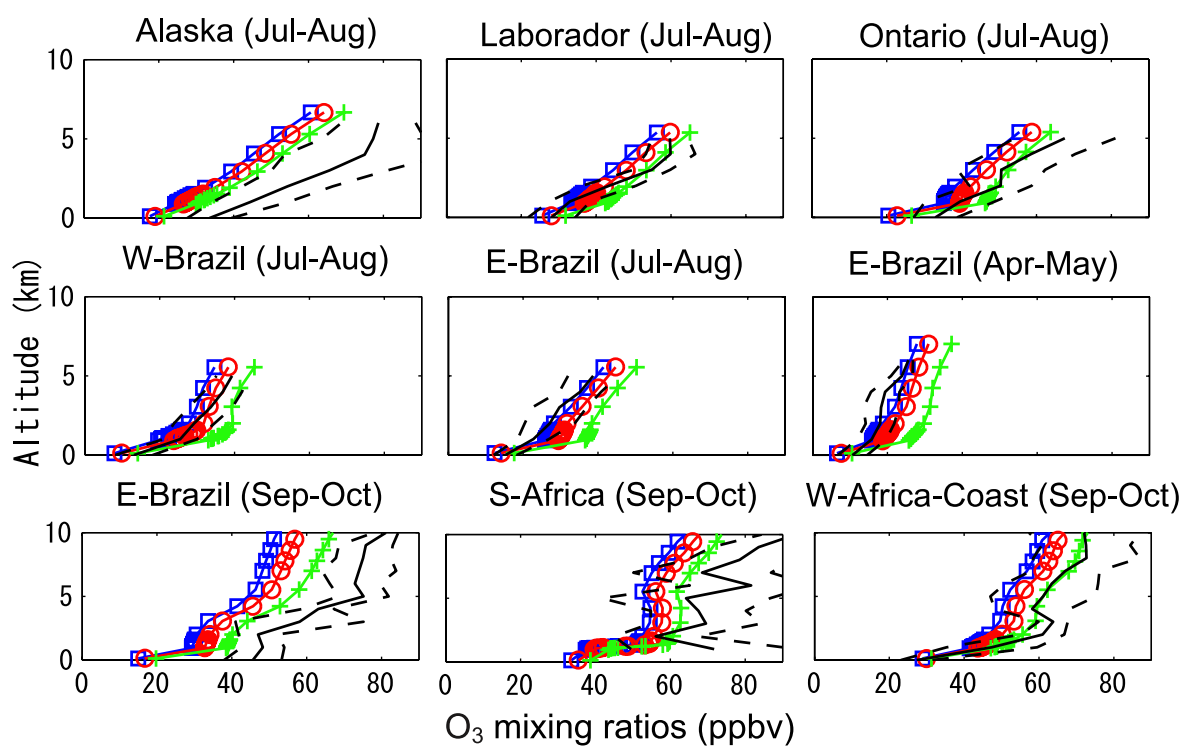

Figure 7. Comparison between measured $\mathrm{O}_{3}$ [Emmons et al., 2000] and model results at various sites. The blue lines with squares represent the mixing ratios of $\mathrm{O}_{3}$ with $0 \% \mathrm{NO}_{\mathrm{x}}$ recycling. The red lines with circles denote the mixing ratios of $\mathrm{O}_{3}$ with $40 \% \mathrm{NO}_{\mathrm{x}}$ recycling. The green lines with crosses show the mixing ratios of $\mathrm{O}_{3}$ with $100 \% \mathrm{NO}_{\mathrm{x}}$ recycling. Observations are indicated by the black lines. The black dashed lines show the standard deviations of measured values.

2007a]. Ito et al. [2007a] have shown the comparison between the model and observations for $\Sigma$ PNs and $\Sigma$ ANs with different $\mathrm{NO}_{\mathrm{x}}$ recycling fractions for isoprene nitrates. In section 4.3.1, we provide some additional discussion on the comparison of $\mathrm{O}_{3}$ mixing ratios with measurements. Further, the responses of $\mathrm{O}_{3}, \mathrm{OH}$ and reactive nitrogen compounds to temperature changes are discussed in section 4.3.2.

\subsubsection{Comparisons With Observed $\mathrm{O}_{3}$}

[42] In order to identify whether the changes in the $\mathrm{NO}_{\mathrm{x}}$ recycling fraction affect the agreement of the vertical profile between models and measurements, the average $\mathrm{O}_{3}$ mixing ratios from the simulations with low, middle, and high $\mathrm{NO}_{\mathrm{x}}$ recycling fractions are compared with ambient measurements (Figure 7). The observational data set was compiled from field campaigns over selected regions and dates by Emmons et al. [2000].

[43] The uncertainty ranges in $\mathrm{O}_{3}$ mixing ratios due to different $\mathrm{NO}_{\mathrm{x}}$ recycling fractions over tropical regions (10 ppbv) are larger than those at northern midlatitudes (8 ppbv) during summer. The ranges over East Brazil (14 ppbv) during the Amazonian forest fire season for September and October are larger than those for other seasons. The ranges are larger at higher altitudes (around $8 \mathrm{~km}$ ) than those at lower altitudes around $2 \mathrm{~km}$ (10ppbv). Ito et al. [2007a] showed that the surface $\mathrm{O}_{3}$ mixing ratios for these regions were sensitive to different emission estimates from biomass burning but that those at higher altitudes (around $8 \mathrm{~km}$ ) were less sensitive. These results suggest that measurements in the FT over isoprene-rich locations in regions with high- $\mathrm{NO}_{\mathrm{x}}$ emissions may provide constraints on the $\mathrm{NO}_{\mathrm{x}}$ recycling fraction.

\subsubsection{Comparison of Sensitivities to Temperature}

[44] Even if models agree with the current $\mathrm{O}_{3}$ measurements, it would not necessarily guarantee that the models could predict the future $\mathrm{O}_{3}$ well, as we showed by examining the response of $\mathrm{O}_{3}$ to temperature changes due to different $\mathrm{NO}_{\mathrm{x}}$ recycling rates. However, the model should represent the response of $\mathrm{O}_{3}$ to short-term changes before extrapolating it to long-term changes. The ability of models to predict the response of $\mathrm{O}_{3}$ to short-term changes in temperature can be evaluated in part by examining how ambient concentrations of $\mathrm{O}_{3}$ and other related species respond to day-to-day variations in temperature. It is well known that $\mathrm{O}_{3}$ in polluted regions shows a strong correlation with temperature [e.g., Sillman and Samson, 1995]. Recently, Day et al. [2008] reported measurements for the variation of $\mathrm{O}_{3}$ and various reactive nitrogen species with temperature at the University of California-Blodgett Forest Research Station (UC-BFRS) (1315 m above sea level, $\left.38.9^{\circ} \mathrm{N}, 120.6^{\circ} \mathrm{W}\right)$ during the summer of 2001. This location is a forested in the Sierra foothills and is removed from immediate anthropogenic influence, but is strongly influenced by urban emissions from Sacramento $(80 \mathrm{~km}$ to the northwest) and other urban centers in the San Joaquin valley. Here we examine the predicted correlations with temperatures from model simulations for the same time period in comparison with measured values. These day-today variations with temperature are largely influenced by changes in reaction rates and in biogenic emissions associated with temperature [e.g., Steiner et al., 2006; Day et al., 2008]. Correlations with temperature can also be influenced by meteorological patterns, such as correlations between winds, vertical diffusion or cloudiness with temperature [e.g., Jacob et al., 1993], although Day et al. [2008] concluded that these had a relatively minor influence at $\mathrm{UC}-\mathrm{BFRS}$ during the time period.

[45] Table 3 shows the response of $\mathrm{O}_{3}, \mathrm{OH}$, and the reactive nitrogen species to day-to-day temperature changes based on model results for low and high horizontal resolution with different $\mathrm{NO}_{\mathrm{x}}$ recycling fractions ( $\mathrm{L}_{-} 0, \mathrm{~L}_{-} 40$, H_40, and H_100) and those reported by Day et al. [2008] at UC-BFRS from June to September. Day et al. 
Table 3. Model Results Compared With $\mathrm{O}_{3}$ and Reactive Nitrogen Compounds Measured and OH Inferred From the Observations of Temperature Trends in the $\mathrm{HNO}_{3} / \mathrm{NO}_{2}$ Ratio at Blodgett Forest Research Station by Day et al. [2008] ${ }^{\mathrm{a}}$

\begin{tabular}{|c|c|c|c|c|c|}
\hline & $\mathrm{L} \_0$ & L_40 & H_40 & H_100 & Day et al. $[2008]$ \\
\hline \multicolumn{6}{|c|}{ Mean Value at $298 \mathrm{~K}$} \\
\hline $\mathrm{O}_{3}$ (ppbv) & 56 & 58 & 51 & 57 & 64 \\
\hline $\mathrm{NO}_{\mathrm{x}}$ (ppbv) & 0.92 & 0.98 & 0.24 & 0.35 & 0.7 \\
\hline $\mathrm{NO}_{\mathrm{z}}(\mathrm{ppbv})$ & 2.8 & 2.9 & 2.0 & 2.3 & 2.3 \\
\hline $\mathrm{OH}\left(10^{6}\right.$ molecules $\left.\mathrm{cm}^{-3}\right)$ & 8.8 & 9.3 & 2.2 & 2.8 & 18 \\
\hline$\Sigma \mathrm{PNs} / \mathrm{NO}_{\mathrm{z}}$ & 0.26 & 0.26 & 0.19 & 0.22 & 0.49 \\
\hline$\Sigma \mathrm{ANs} / \mathrm{NO}_{\mathrm{z}}$ & 0.13 & 0.10 & 0.15 & 0.10 & 0.20 \\
\hline $\mathrm{HNO}_{3} / \mathrm{NO}_{\mathrm{z}}$ & 0.61 & 0.64 & 0.66 & 0.68 & 0.42 \\
\hline $\mathrm{HNO}_{3} / \mathrm{NO}_{2}$ & 2.6 & 2.6 & 7.4 & 6.3 & 2.0 \\
\hline \multicolumn{6}{|c|}{ Slope $K^{-1}$} \\
\hline $\mathrm{O}_{3}(\mathrm{ppbv})$ & +2.5 & +2.8 & +1.4 & +2.0 & +2.2 \\
\hline $\mathrm{NO}_{\mathrm{x}}$ (ppbv) & +0.011 & +0.015 & +0.006 & +0.015 & -0.0007 \\
\hline $\mathrm{NO}_{z}(\mathrm{ppbv})$ & +0.11 & +0.13 & +0.11 & +0.14 & +0.036 \\
\hline $\mathrm{OH}\left(10^{6}\right.$ molecules $\left.\mathrm{cm}^{-3}\right)$ & -0.29 & -0.27 & -0.031 & -0.008 & +1.1 \\
\hline$\Sigma \mathrm{PNs} / \mathrm{NO}_{\mathrm{z}}$ & -0.014 & -0.013 & -0.019 & -0.018 & -0.023 \\
\hline$\Sigma \mathrm{ANs} / \mathrm{NO}_{\mathrm{z}}$ & +0.0037 & +0.0022 & -0.0001 & -0.0009 & +0.0036 \\
\hline $\mathrm{HNO}_{3} / \mathrm{NO}_{\mathrm{z}}$ & +0.0098 & +0.011 & +0.019 & +0.019 & +0.019 \\
\hline $\mathrm{HNO}_{3} / \mathrm{NO}_{2}$ & +0.081 & +0.084 & +0.35 & +0.22 & +0.11 \\
\hline
\end{tabular}

${ }^{\text {a }}$ The model results of L_0, L_40, H_40, and H_100 and the measurements are for 1200-1600 LT, 1 June to 30 September 2001.

[2008] observed the sum of gas-phase $\mathrm{HNO}_{3}$ and thermally labile $\mathrm{HNO}_{3}$ aerosols such as $\mathrm{NH}_{4} \mathrm{NO}_{3}$. However, Day et al. [2008] concluded that any aerosol $\mathrm{NO}_{3}^{-}$in the region was nonvolatile and would not have been detected as part of their measurements of $\mathrm{HNO}_{3}$. Similarly, Day et al. [2008] observed the sum of all alkyl and multifunctional nitrates present in the gas or aerosol phase. Thus we calculate the total alkyl nitrate in our model for comparison with their observations. The afternoon (1200-1600 LT) medians of $\mathrm{O}_{3}, \mathrm{OH}$, and the reactive nitrogen species are calculated for each day of summer 2001. The slope is calculated from a least squares fit to the median and the daily maximum temperature. The mean value for each species at $298 \mathrm{~K}$ is estimated from the function for each scenario. Day et al. [2008] excluded the observations on Saturday through Monday and days where trace gas species were influenced by forest fires from the measured values. We present here all days from the model results of $\mathrm{L} \_0, \mathrm{~L} \_40, \mathrm{H} \_40$, and $\mathrm{H} \_40$, since we did not include week $\overline{d a y}$-weeken $\bar{d}$ differences in emissions or event-specific forest fires in the model (Figures $8-10$ ). Thus the total number of days included in our analysis (122) is larger than that for measured values (63).

\subsubsection{1. $\Sigma$ PNs, $\Sigma$ ANs, and $\mathrm{HNO}_{3}$}

[46] Comparisons between model results and measurements at the UC-BFRS site are difficult because the coarse horizontal resolution does not account for the distinctive local geography, in which anthropogenic emissions from urban sources are transported to the measurement site in a region with high-BVOC emissions. The model includes both the Sacramento urban area $(80 \mathrm{~km}$ upwind from UC-BFRS) and the UC-BFRS site within the same horizontal grid for the low and middle resolutions but not for the high-resolution model $\left(1^{\circ} \times 1^{\circ}\right)$. However, it is noteworthy that the ratios of the relatively long lived $\mathrm{NO}_{\mathrm{x}}$ reaction products ( $\Sigma \mathrm{PNs}, \Sigma \mathrm{ANs}$, and $\mathrm{HNO}_{3}$ ) to $\mathrm{NO}_{\mathrm{z}}$ show variations with temperature that are comparable with measurements (Figure 8). The correlation coefficients of $\Sigma \mathrm{PNs} /$ $\mathrm{NO}_{\mathrm{z}}(0.46), \Sigma \mathrm{ANs} / \mathrm{NO}_{\mathrm{z}}(0.17)$, and $\mathrm{HNO}_{3} / \mathrm{NO}_{\mathrm{z}}(0.27)$ with temperature are comparable to that of Day et al. [2008] $\left(0.52,0.069\right.$, and 0.37 , respectively). Despite the low $R^{2}$ values, Figure 8 shows that the regression lines capture the major patterns present in the data. The model slopes versus temperature are all statistically significant at a $95 \%$ confidence interval except for $\Sigma \mathrm{ANs} / \mathrm{NO}_{\mathrm{z}}$, which shows a weak dependence on temperature in both the model and measurements. The match of the model trend to observed trend varies with the model simulation, but the $\mathrm{H} 40$ trends versus temperature for $\Sigma \mathrm{PNs} / \mathrm{NO}_{\mathrm{z}}\left(-0.02 \overline{\mathrm{ppb} \mathrm{K}}{ }^{-1}\right)$, $\Sigma A N s / \mathrm{NO}_{\mathrm{z}}\left(0.00 \mathrm{ppb} \mathrm{K}{ }^{-1}\right)$, and $\mathrm{HNO}_{3} / \mathrm{NO}_{\mathrm{z}}\left(0.02 \mathrm{~K}^{-1}\right)$ are noticeably closer to the observed trends. The ratio of $\Sigma$ PNs to $\mathrm{NO}_{\mathrm{z}}$ decreases, the ratio of $\Sigma \mathrm{ANs}$ to $\mathrm{NO}_{\mathrm{z}}$ does not change, and the ratio of $\mathrm{HNO}_{3}$ to $\mathrm{NO}_{\mathrm{z}}$ increases with increasing temperature both in the model and in the measurements. The mixing ratios of $\mathrm{NO}_{\mathrm{z}}$ in model are in good agreement (within 26\%) with observations, while the ratios of $\Sigma$ PNs, $\Sigma$ ANOs, and $\mathrm{HNO}_{3}$ to $\mathrm{NO}_{\mathrm{z}}$ in the model differ significantly from the measured values at $\mathrm{UC}-\mathrm{BFRC}$. The model underestimates $\Sigma \mathrm{PNs} / \mathrm{NO}_{\mathrm{z}}$ and $\Sigma \mathrm{ANs} / \mathrm{NO}_{\mathrm{z}}$ but overestimates $\mathrm{HNO}_{3} / \mathrm{NO}_{\mathrm{z}}$, possibly suggesting that the anthropogenic $\mathrm{NO}_{\mathrm{x}}$ is more quickly converted to oxidized products by reactions with $\mathrm{OH}$ than by those with $\mathrm{RO}_{2}$ under urban area conditions in the model where $\mathrm{OH}$ is high and $\mathrm{BVOC}$ emissions are low.

4.3.2.2. $\mathrm{O}_{3}$

[47] The model scenarios also estimate that day-to-day ambient $\mathrm{O}_{3}$ correlates with temperature $\left(R^{2}=0.55\right.$ for $\mathrm{L} 0$, 0.56 for $\mathrm{L} 40,0.25$ for $\mathrm{H} 40$ and 0.34 for $\mathrm{H} 100$ ) and that the rate of increase is comparable to the observed increase at UC-BFRC. The model scenarios that use a $0 \% \mathrm{NO}_{\mathrm{x}}$ recycling fraction in the low-resolution model and $100 \%$ $\mathrm{NO}_{\mathrm{x}}$ recycling in the high-resolution model show increased $\mathrm{O}_{3}\left(2.5\right.$ and $\left.2.0 \mathrm{ppbv} \mathrm{K}^{-1}\right)$ with temperature that is comparable to the observed slope in $\mathrm{O}_{3}$ versus temperature $\left(2.2 \mathrm{ppbv} \mathrm{K}^{-1}\right)$. Our $\mathrm{O}_{3}$ mixing ratios $(58 \mathrm{ppbv}$ at $298 \mathrm{~K}$ for L 40) are also in good agreement with the observations (Figure 8).

\subsubsection{3. $\Sigma$ ANs and $\mathrm{O}_{3}$}

[48] Horowitz et al. [2007] found higher slope with higher $\mathrm{NO}_{\mathrm{x}}$ recycling $\left(100 \% ; 257 \mathrm{O}_{3}\right.$ per $\left.\Sigma \mathrm{ANs}\right)$ but lower slope with higher yield of isoprene nitrate $\left(8 \% ; 62 \mathrm{O}_{3}\right.$ per 

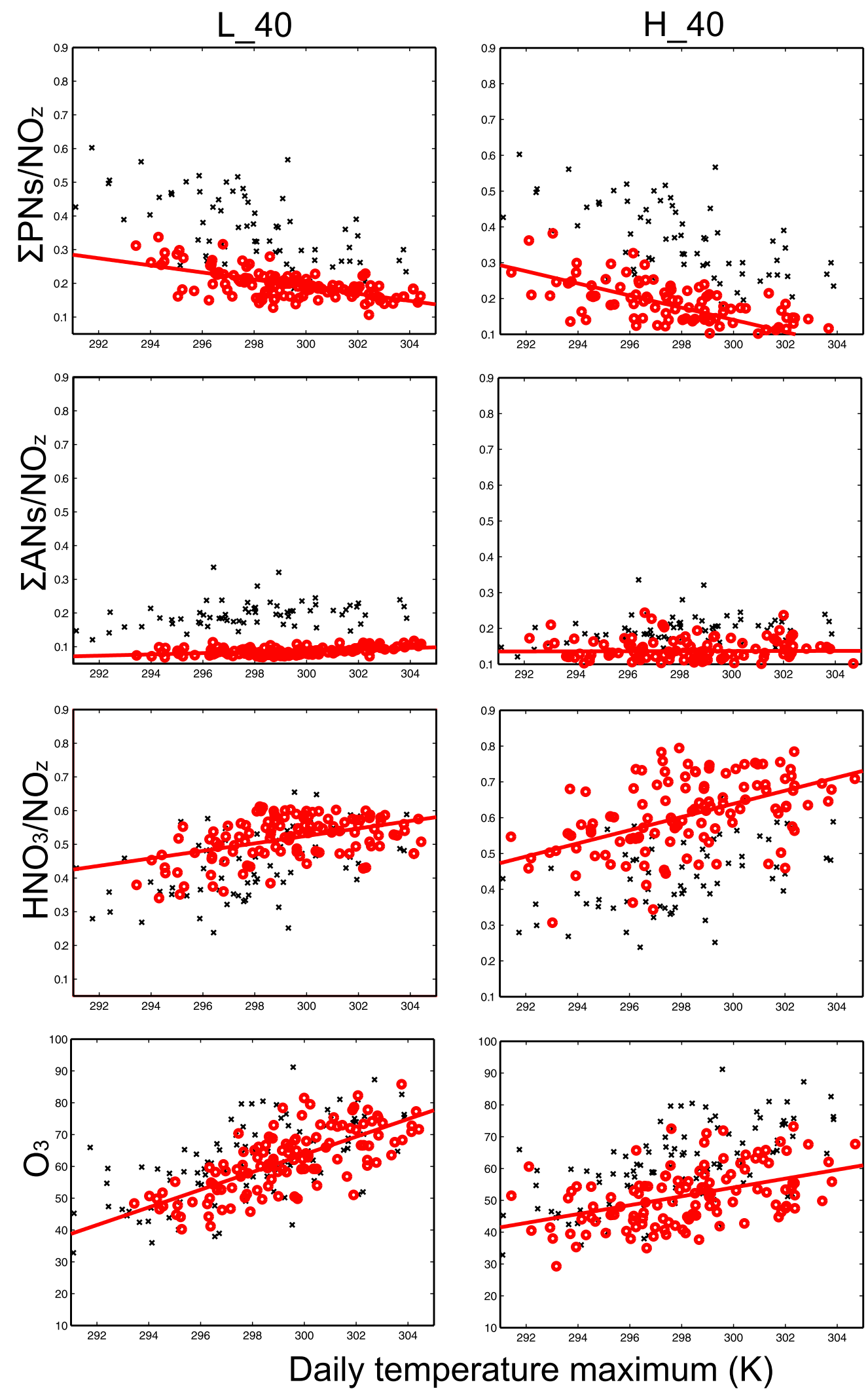

Figure 8. Modeled (red) and observed (black) $\Sigma \mathrm{PNs} / \mathrm{NO}_{\mathrm{z}}, \Sigma \mathrm{ANs} / \mathrm{NO}_{\mathrm{z}}, \mathrm{HNO}_{3} / \mathrm{NO}_{\mathrm{z}}$, and $\mathrm{O}_{3}$ versus daily maximum temperature $(\mathrm{K})$ for 1200-1600 LT, June to September 2001 (L_40 and H_40 simulations) at UC-BFRS. 

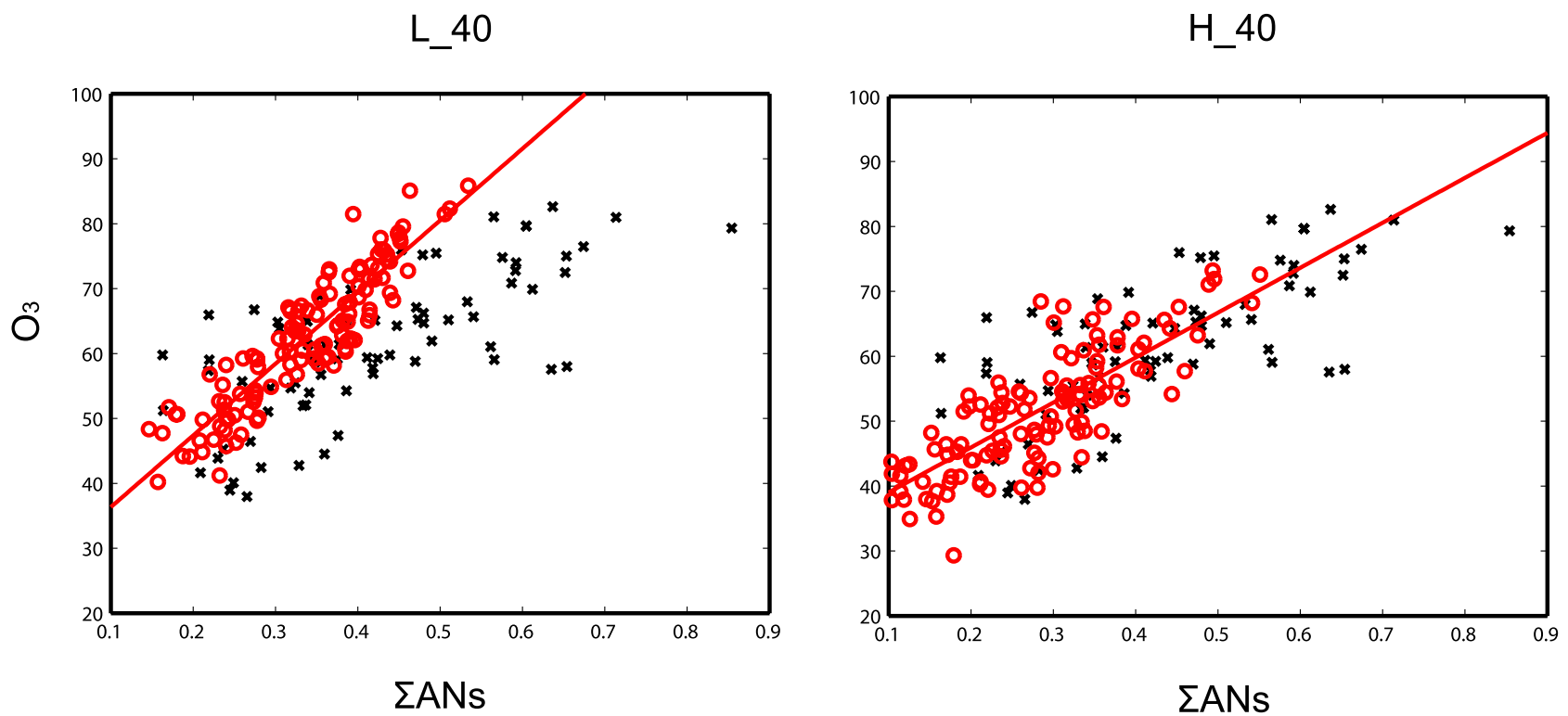

Figure 9. Modeled (red) and observed (black) $\mathrm{O}_{3}$ versus $\Sigma$ ANs for 1200-1600 LT, June to September 2001 (L_40 and H_40 simulations) at UC-BFRS.

$\Sigma$ ANs). Our results in the surface air using the high yield of isoprene nitrate show lower slope with higher resolution (106 for L_40 versus 69 for H_40) (Figure 9). The slope between model $\mathrm{O}_{3}$ and $\Sigma$ ANs shows similar sensitivity to the model resolution as to $\mathrm{NO}_{\mathrm{x}}$ recycling from isoprene nitrates (69 for $\mathrm{H}_{-} 40$ versus 106 for $\mathrm{H}_{-} 100$ ). These results suggest that the assumptions of higher yield of isoprene nitrate and higher $\mathrm{NO}_{\mathrm{x}}$ recycling fractions using higherresolution simulation might be able to match the slope of $\mathrm{O}_{3}$ per $\Sigma$ ANs.

\subsubsection{4. $\mathrm{OH}$}

[49] Typically, models underestimate $\mathrm{OH}$ concentrations in regions with high-VOC and low-NO mixing ratios [e.g., Carslaw et al., 2001; Tan et al., 2001; Thornton et al., 2002; Karl et al., 2007; Kuhn et al., 2007; Farmer and Cohen, 2008; Ren et al., 2008]. A key question here with regard to the temperature dependency of $\mathrm{OH}$ is whether $\mathrm{OH}$ increases with temperature owing to the ozonolysis of unidentified reactive $\mathrm{BVOC}$ as a temperature-dependent source of $\mathrm{OH}$ in the atmosphere [Kurpius and Goldstein, 2003; Di Carlo et al., 2004] or owing to the efficient $\mathrm{OH}$ recycling via $\mathrm{HO}_{2}+$ $\mathrm{RO}_{2}$ reactions which occur in an unpolluted low- $\mathrm{NO}_{\mathrm{x}}$ environment [Thornton et al., 2002; Lelieveld et al., 2008; Butler et al., 2008]. In the former case, the sensitivity of $\mathrm{O}_{3}$ to the assumed $\mathrm{NO}_{\mathrm{x}}$ recycling fraction may be less important, because the additional $\mathrm{OH}$ sources would partition anthropogenic $\mathrm{NO}_{\mathrm{x}}$ into $\mathrm{HNO}_{3}$ with warmer temperatures. In the latter case, the assumed $\mathrm{NO}_{\mathrm{x}}$ recycling fraction can have a large influence on anthropogenic $\mathrm{NO}_{\mathrm{x}}$, but it depends on how much $\mathrm{OH}$ forms relative to BVOC and NO levels.

[50] Day et al. [2008] infer that $\mathrm{OH}$ rapidly increases with temperature in the mixed layer, on the basis of the observed increase in the ratio of $\mathrm{HNO}_{3} / \mathrm{NO}_{2}$ with increasing temperature. The model $\mathrm{OH}$ concentrations in the high-resolution version $\left(2-3 \times 10^{6}\right.$ molecules $\left.\mathrm{cm}^{-3}\right)$ are lower than inferred value at UC-BFRC $\left(18 \times 10^{6}\right.$ molecules $\left.\mathrm{cm}^{-3}\right)$.
The low $\mathrm{OH}$ at high resolution is probably due to the low $\mathrm{NO}_{\mathrm{x}}(0.2-0.4 \mathrm{ppb})$. The measured $\mathrm{NO}_{\mathrm{x}}(0.7 \mathrm{ppb})$ is influenced by transport of $\mathrm{NO}_{\mathrm{x}}$ from urban source regions to the UC-BFRC site by a strong mountain/valley wind over the western slope of the Sierra Nevada [Murphy et al., 2006]. In the low-resolution simulation, our $\mathrm{OH}\left(9 \times 10^{6}\right.$ molecules $\mathrm{cm}^{-3}$ ) is in better agreement with the inferred value than the model at the high resolution, probably because the conditions in the low-resolution version represent relatively high- $\mathrm{NO}_{\mathrm{x}}$ conditions $(0.98 \mathrm{ppb}$ at $298 \mathrm{~K}$ for L 40), which are in much better agreement with the observations. In the low-resolution model simulations (Figure 10), $\mathrm{OH}$ in the afternoon is calculated to decrease with temperature $\left(-0.27 \times 10^{6}\right.$ molecules $\mathrm{cm}^{-3} \mathrm{~K}^{-1}$ for $\mathrm{L} 40$ ), in contrast to the behavior of $\mathrm{OH}$ inferred. Thus one might argue that the additional $\mathrm{OH}$ required to match the inferred increase in $\mathrm{OH}$ with temperature might be explained by the ozonolysis of unidentified reactive BVOC as a temperature-dependent source of $\mathrm{OH}$ in the atmosphere [Kurpius and Goldstein, 2003; Di Carlo et al., 2004]. However, the model results for $\mathrm{HNO}_{3} / \mathrm{NO}_{2}(2.6$ at $298 \mathrm{~K})$ and its increase with temperature $\left(0.08 \mathrm{~K}^{-1}\right)$ are in good agreement with the measurements without the assumption of a temperature-dependent source of $\mathrm{OH}$.

[51] The increases in $\mathrm{HNO}_{3}$ with temperature can be associated with changes in the PAN thermal equilibrium providing increased $\mathrm{NO}_{2}$, which reacts with $\mathrm{OH}$ to form $\mathrm{HNO}_{3}$. The increases in both $\mathrm{OH}$ and $\mathrm{NO}_{2}$ versus temperature can be seen earlier in the day, but are no longer visible in the model afternoon values. A similar tendency appeared in the calculations reported by Sillman and Samson [1995]. The observed increase in $\mathrm{HNO}_{3} / \mathrm{NO}_{2}$ with temperature reported by Day et al. [2008] may also reflect increases in $\mathrm{HNO}_{3}$ in upwind urban areas rather than changes in $\mathrm{OH}$ at the site. Murphy et al. [2006] suggested that the observed $\mathrm{NO}_{\mathrm{y}}$ at noon at $\mathrm{UC}-\mathrm{BFRS}$ reflected urban emissions during 

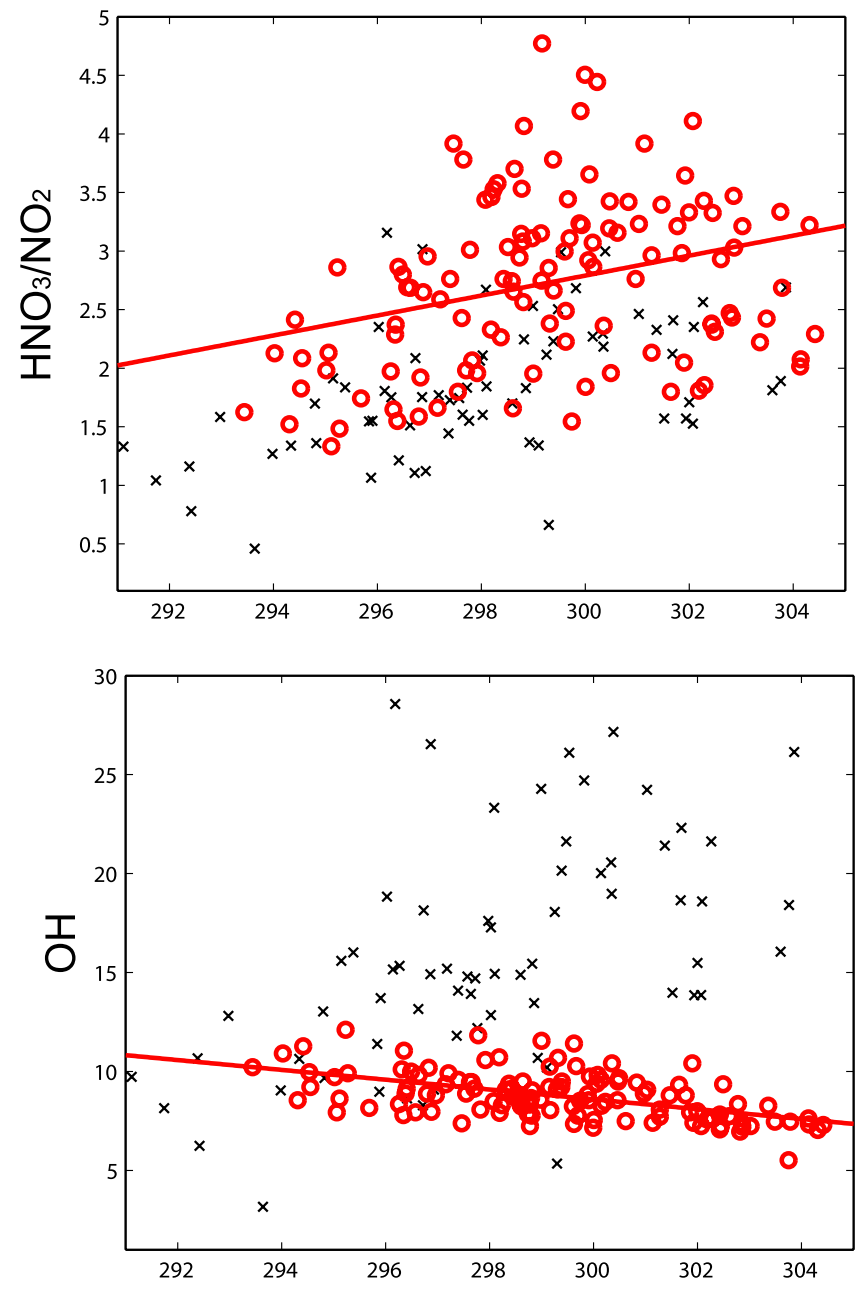

Daily temperature maximum $(\mathrm{K})$

Figure 10. Modeled (red) and observed/inferred (black) $\mathrm{HNO}_{3} / \mathrm{NO}_{2}$ and $\mathrm{OH}$ versus daily maximum temperature $(\mathrm{K})$ for 1200-1600 LT, June to September 2001 (L_40 simulation) at $\mathrm{UC}-\mathrm{BFRS}$.

the morning rush hour located 5-6 h upwind. As noted by Day et al. [2008] and Farmer and Cohen [2008], $\mathrm{HNO}_{3}$ is produced more rapidly upwind where $\mathrm{NO}_{2}$ mixing ratios are much higher [Murphy et al., 2006]. Thus the overestimate of $\mathrm{OH}$ and its increase with temperature in the steady state calculation from the $\mathrm{HNO}_{3} / \mathrm{NO}_{2}$ ratio is probably associated with the content of the transported air (i.e., increased $\mathrm{HNO}_{3}$ with temperature in the upwind urban areas). In this context, Sillman and Samson [1995] reported that $\mathrm{OH}$ and $\mathrm{HNO}_{3}$ / $\mathrm{NO}_{2}$ both increase sharply with temperature in calculations for an urban location. Further, Lelieveld et al. [2008] and Butler et al. [2008] calculated an insignificant change in $\mathrm{OH}$ $( \pm 5 \%)$ during June, July, and August over this region when they changed the fraction of $\mathrm{OH}$ recycling associated with isoprene oxidation. Thus, at moderately high $\mathrm{NO}_{\mathrm{x}}$ conditions, $\mathrm{OH}$ concentrations are not expected to increase significantly as a result of $\mathrm{OH}$ recycling. In this context it is noteworthy that our $\mathrm{OH}$ in the low-resolution model is in fairly good agreement with that of Dillon et al. [2002], who calculated $\mathrm{OH}\left(11 \pm 5 \times 10^{6}\right.$ molecules $\left.\mathrm{cm}^{-3}\right)$ in the
Sacramento urban plume using a Lagrangian model and VOC measurements.

[52] Finally, model results using the low- and highresolution versions for July are also compared with measurements of isoprene, $\mathrm{OH}$, and $\mathrm{NO}$ from three summer field campaigns: AEROBIC97 $\left(39.9^{\circ} \mathrm{N}, 21.7^{\circ} \mathrm{E}\right)$, PROPHET98 $\left(45.6^{\circ} \mathrm{N}, 84.7^{\circ} \mathrm{W}\right)$, and PMTACS-NY $\left(44.4^{\circ} \mathrm{N}\right.$, $\left.73.9^{\circ} \mathrm{W}\right)($ Table 4$)$. The model results at rural sites are in good agreement with the daytime peak $\mathrm{OH}$ levels in the Northern Hemisphere [Carslaw et al., 2001; Tan et al., 2001; Ren et al., 2006]. These results might justify the predictability of the model at the rural sites to support our interpretation over isoprene-emitting regions near polluted source areas. On the other hand, Butler et al. [2008] have shown that the modeled $\mathrm{OH}$ concentrations over the three sites were too high with artificial $\mathrm{OH}$ recycling. Clearly, further work is needed to investigate the role of $\mathrm{OH}$ relative to BVOC and NO mixing ratios before the practical application of $\mathrm{OH}$ recycling to CTM.

\section{Summary and Conclusions}

[53] We investigated the effects of temperature changes $( \pm 5 \mathrm{~K})$ on $\mathrm{O}_{3}$ mixing ratios by examining changes in BVOC emissions and chemistry reaction rate coefficients. Our focus was to elucidate the relationship between the treatment of isoprene nitrates and the horizontal resolution in the model and to evaluate the ability of the model to predict temperature-dependent responses of $\mathrm{O}_{3}$ and long-lived $\mathrm{NO}_{\mathrm{x}}$ reaction products ( $\Sigma \mathrm{PNs}, \Sigma \mathrm{ANs}$, and $\mathrm{HNO}_{3}$ ) on the basis of observed response.

[54] Global CTM calculations showed that the increases in the tropospheric $\mathrm{O}_{3}$ burden as a result of the increases in BVOC, in particular isoprene $\left(270-940 \mathrm{TgC} \mathrm{a}^{-1}\right)$, emissions associated with temperature increases strongly depended on the assumption of the amount of recycling of $\mathrm{NO}_{\mathrm{x}}$ from isoprene nitrates $\left(17-57 \mathrm{Tg}\right.$ for $0-100 \% \mathrm{NO}_{\mathrm{x}}$ recycling). Substantial differences in the global mean $\mathrm{O}_{3}$ burden $(40 \mathrm{Tg})$ were caused by the differences in the

Table 4. Measured $\mathrm{OH}$ Concentrations and Mixing Ratios of Isoprene and $\mathrm{NO}$ at Local Noon From Field Measurements Compared With Model Simulations ${ }^{\mathrm{a}}$

\begin{tabular}{lccccc}
\hline \hline & L_0 & L_40 & H_40 & H_100 & AEROBIC97 \\
\hline Isoprene $^{\mathrm{b}}$ & 0.59 & 0.52 & 1.9 & 1.6 & 1 \\
$\mathrm{NO}^{\mathrm{c}}$ & 33 & 43 & 85 & 113 & $<100$ \\
$\mathrm{OH}^{\mathrm{c}}$ & 3.4 & 4.1 & 2.3 & 3.1 & 4 \\
\hline & $\mathrm{L} \_0$ & $\mathrm{~L} \_40$ & $\mathrm{H} \_40$ & $\mathrm{H} \_100$ & PROPHET98 \\
\hline Isoprene $^{\mathrm{d}}$ & 0.58 & 0.51 & 2.2 & 1.7 & 2 \\
$\mathrm{NO}^{\mathrm{e}}$ & 148 & 157 & 40 & 60 & $<100$ \\
$\mathrm{OH}^{\mathrm{e}}$ & 4.7 & 5.3 & 1.4 & 2.0 & 4 \\
\hline & $\mathrm{L} \_0$ & $\mathrm{~L} \_40$ & $\mathrm{H} \_40$ & $\mathrm{H} \_100$ & PMTACS-NY \\
\hline Isoprene $^{\mathrm{f}}$ & 0.93 & 0.85 & 2.0 & 1.6 & $<1$ \\
$\mathrm{NO}^{\mathrm{f}}$ & 178 & 187 & 130 & 150 & $\approx 100$ \\
$\mathrm{OH}^{\mathrm{f}}$ & 4.1 & 4.5 & 2.2 & 2.7 & 3 \\
\hline \hline
\end{tabular}

${ }^{\mathrm{a}}$ Units are $\times 10^{6}$ molecules $\mathrm{cm}^{-3}$ for $\mathrm{OH}$ concentrations, ppbv for mixing ratios of isoprene, and pptv for mixing ratios of NO.

${ }^{\mathrm{b}}$ Harrison et al. [2001].

${ }^{c}$ Carslaw et al. [2001].

${ }^{\mathrm{d}}$ Apel et al. [2002].

${ }^{\mathrm{e}}$ Tan et al. [2001].

${ }^{\mathrm{f}}$ Ren et al. [2006]. 
assumption of the amount of recycling of $\mathrm{NO}_{\mathrm{x}}$ from isoprene nitrates between $0 \%$ and $100 \%$. These differences were equivalent to the differences in the model resolution between the high resolution $(302 \mathrm{Tg})$ and the low with the $40 \% \mathrm{NO}_{\mathrm{x}}$ recycling fraction $(340 \mathrm{Tg}$ ). Our results in the surface air at a forested site in California showed lower slope with higher resolution (106 for L_40 versus 69 for $\mathrm{H} 40)$. The slope between model $\mathrm{O}_{3}$ and $\Sigma$ ANs showed similar sensitivity to the model resolution as to $\mathrm{NO}_{\mathrm{x}}$ recycling from isoprene nitrates (69 for $\mathrm{H}_{-} 40$ versus 106 for $\mathrm{H} 100)$. The model versus measured slope might be used to infer the yield of isoprene nitrate and $\mathrm{NO}_{\mathrm{x}}$ recycling fraction. However, our results indicate that the model slope and the recycling efficiencies of $\mathrm{NO}_{\mathrm{x}}$ in a CTM are related to the isoprene nitrate chemistry as well as the grid resolution. It suggests that better agreement in the response of $\mathrm{O}_{3}$ to temperature increases with observations could be achieved by using higher-resolution model with higher yield of isoprene nitrate and higher $\mathrm{NO}_{\mathrm{x}}$ recycling fraction from isoprene nitrate.

[55] Model results have been compared with the observed responses in $\mathrm{O}_{3}$ and reactive nitrogen compounds to temperature at a forested site in California observed by Day et al. [2008]. The model result showed a rapid increase in $\mathrm{O}_{3}$ $\left(2.0 \mathrm{ppb} \mathrm{K}{ }^{-1}\right)$ and $\mathrm{HNO}_{3} / \mathrm{NO}_{\mathrm{z}}\left(0.02 \mathrm{~K}^{-1}\right)$, little change in $\Sigma$ ANs $/ \mathrm{NO}_{\mathrm{z}}\left(0.00 \mathrm{ppb} \mathrm{K}{ }^{-1}\right)$ and a decrease in $\Sigma \mathrm{PNs} / \mathrm{NO}_{\mathrm{z}}$ $\left(-0.02 \mathrm{ppb} \mathrm{K} \mathrm{K}^{-1}\right)$ with increasing temperatures in the surface air. These compare closely with the measured variations, although the agreement varies with scenarios and species considered (see Table 3 and Figure 8). These results might justify the predictability of the model at the rural sites to support our interpretation over isoprene-emitting regions near polluted source areas. However, the interactions of terrestrial ecosystems with human activities and climate change are highly complex and the temperature sensitivities of $\mathrm{O}_{3}$ may vary in different conditions. Further work is needed to provide constraints on the response of $\mathrm{O}_{3}$ to temperature increases for a more accurate model prediction of effect of climate change on air quality.

[56] Acknowledgments. We thank R. C. Cohen and his colleagues for kindly providing the observational data set at UC-BFRS. Support for this research was provided to A. Ito by the Innovative Program of Climate Change Projection for the 21 st Century (MEXT) and to J. E. Penner and S. Sillman by the U.S. National Science Foundation (grant ATM 0454838) and the Environmental Protection Agency (STAR grant RD83337701-0). All of the global simulations in this study were performed using the SGI Altix4700 at the JAMSTEC. We wish to thank X. Liu for making the AeroCom emission data available for use in IMPACT.

\section{References}

Allen, D. J., and K. E. Pickering (2002), Evaluation of lightning flash rate parameterizations for use in a global chemical transport model, J. Geophys. Res., 107(D23), 4711, doi:10.1029/2002JD002066.

Apel, E. C., et al. (2002), Measurement and interpretation of isoprene fluxes and isoprene, methacrolein, and methyl vinyl ketone mixing ratios at the PROPHET site during the 1998 Intensive, J. Geophys. Res., 107(D3), 4034, doi:10.1029/2000JD000225.

Arneth, A., P. A. Miller, M. Scholze, T. Hickler, G. Schurgers, B. Smith, and I. C. Prentice (2007), $\mathrm{CO}_{2}$ inhibition of global terrestrial isoprene emissions: Potential implications for atmospheric chemistry, Geophys. Res. Lett., 34, L18813, doi:10.1029/2007GL030615.

Arneth, A., R. K. Monson, G. Schurgers, Ü. Niiemets, and P. I. Palmer (2008), Why are estimates of global terrestrial isoprene emissions so similar (and why is this not so for monoterpenes)?, Atmos. Chem. Phys., $8,4605-4620$.
Atkinson, R., D. L. Baulch, R. A. Cox, J. N. Crowley, R. F. Hampson, R. G. Hynes, M. E. Jenkin, M. J. Rossi, and J. Troe (2004), Evaluated kinetic and photochemical data for atmospheric chemistry: Volume 1 - gas phase reactions of $\mathrm{O}_{\mathrm{x}}, \mathrm{HO}_{\mathrm{x}}, \mathrm{NO}_{\mathrm{x}}$, and $\mathrm{SO}_{\mathrm{x}}$, species, Atmos. Chem. Phys., 4, $1461-1738$.

Bey, I., D. Jacob, R. Yantosca, J. Logan, B. Field, A. Fiore, Q. Li, H. Liu, L. Mickley, and M. Schultz (2001), Global modeling of tropospheric chemistry with assimilated meteorology: Model description and evaluation, J. Geophys. Res., 106(D19), 23,073-23,096, doi:10.1029/ 2001JD000807.

Brasseur, G. P., J. T. Kiehl, J.-F. Müller, T. Schneider, C. Granier, X. Tie, and D. Hauglustaine (1998), Past and future changes in global tropospheric ozone: Impact on radiative forcing, Geophys. Res. Lett., 25(20), 3807-3810, doi:10.1029/1998GL900013.

Brasseur, G. P., M. Schultz, C. Granier, M. Saunois, T. Diehl, M. Botzet, E. Roeckner, and S. Walters (2006), Impact of climate change on the future chemical composition of the global troposphere, J. Clim., 19, 3932-3951, doi:10.1175/JCLI3832.1.

Butler, T. M., D. Taraborrelli, C. Brühl, H. Fischer, H. Harder, M. Martinez, J. Williams, M. G. Lawrence, and J. Lelieveld (2008), Improved simulation of isoprene oxidation chemistry with the ECHAM5/MESSy chemistry-climate model: Lessons from the GABRIEL airborne field campaign, Atmos. Chem. Phys., 8, 4529-4546.

Byun, D., and K. L. Schere (2006), Review of the governing equations, computational algorithms, and other components of the Models-3 Community Multiscale Air Quality (CMAQ) modeling system, Appl. Mech. Rev., 59, 51-77, doi:10.1115/1.2128636.

Carslaw, N., et al. (2001), $\mathrm{OH}$ and $\mathrm{HO}_{2}$ radical chemistry in a forested region of north-western Greece, Atmos. Environ., 35, 4725-4737, doi:10.1016/S1352-2310(01)00089-9.

Carter, W. P. L. (2000), Implementation of the SAPRC-99 chemical mechanism into the Models-3 framework, report, U. S. Environ. Prot. Agency, Washington, D. C.

Carter, W. P. L., A. M. Winer, K. R. Darnall, and J. N. Pitts (1979), Smog chamber studies of temperature effects in photochemical smog, Environ. Sci. Technol., 13, 1094-1100, doi:10.1021/es60157a006.

Chen, X., D. Hulbert, and P. B. Shepson (1998), Measurement of the organic nitrate yield from $\mathrm{OH}$ reaction with isoprene, J. Geophys. Res., 103(D19), 25,563-25,568, doi:10.1029/98JD01483.

Dawson, J. P., P. J. Adams, and S. N. Pandis (2007), Sensitivity of ozone to summertime climate in the eastern USA: A modeling case study, Atmos. Environ., 41, 1494-1511, doi:10.1016/j.atmosenv.2006.10.033.

Day, D. A., M. B. Dillon, P. J. Wooldridge, J. A. Thornton, R. S. Rosen, E. C. Wood, and R. C. Cohen (2003), On alkyl nitrates, $\mathrm{O}_{3}$, and the "missing $\mathrm{NO}_{\mathrm{y}}$ ", J. Geophys. Res., 108(D16), 4501, doi:10.1029/ 2003JD003685.

Day, D. A., P. J. Wooldridge, and R. C. Cohen (2008), Observations of the effects of temperature on atmospheric $\mathrm{HNO}_{3}, \Sigma \mathrm{ANs}, \Sigma \mathrm{PNs}$, and $\mathrm{NO}_{\mathrm{x}}$ : Evidence for a temperature dependent $\mathrm{HO}_{\mathrm{x}}$ source, Atmos. Chem. Phys., 8, 1867-1879.

Dentener, F., et al. (2006a), The global atmospheric environment for the next generation, Environ. Sci. Technol., 40, 3586-3594, doi:10.1021/ es0523845.

Dentener, F., et al. (2006b), Emissions of primary aerosol and precursor gases for the years 2000 and 1750 prescribed data-sets for AeroCom, Atmos. Chem. Phys., 6, 4321-4344.

Di Carlo, P., et al. (2004), Missing OH reactivity in a forest: Evidence for unknown reactive biogenic VOCs, Science, 304, 722-725, doi:10.1126/ science.1094392.

Dillon, M. B., M. S. Lamanna, G. W. Schade, A. H. Goldstein, and R. C. Cohen (2002), Chemical evolution of the Sacramento urban plume: Transport and oxidation, J. Geophys. Res., 107(D5), 4045, doi:10.1029/ 2001JD000969.

Emmons, L. K., D. A. Hauglustaine, J.-F. Müller, M. A. Carroll, G. P. Brasseur, D. Brunner, J. Staehelin, V. Thouret, and A. Marenco (2000), Data composites of airborne observations of tropospheric ozone and its precursors, J. Geophys. Res., 105, 20,497-20,538, doi:10.1029/ 2000JD900232.

Farmer, D. K., and R. C. Cohen (2008), Observations of $\mathrm{HNO}_{3}, \Sigma \mathrm{AN}, \Sigma \mathrm{PN}$ and $\mathrm{NO}_{2}$ fluxes: Evidence for rapid $\mathrm{HO}_{\mathrm{x}}$ chemistry within a pine forest canopy, Atmos. Chem. Phys., 8, 3899-3917.

Fehsenfeld, F. C., et al. (2006), International Consortium for Atmospheric Research on Transport and Transformation (ICARTT): North America to Europe-Overview of the 2004 summer field study, J. Geophys. Res., 111, D23S01, doi:10.1029/2006JD007829.

Feng, Y., and J. E. Penner (2007), Global modeling of nitrate and ammonium: Interaction of aerosols and tropospheric chemistry, J. Geophys. Res., 112, D01304, doi:10.1029/2005JD006404.

Fiore, A. M., D. J. Jacob, R. Mathur, and R. V. Martin (2003), Application of empirical orthogonal functions to evaluate ozone simulations with 
regional and global models, J. Geophys. Res., 108(D14), 4431, doi:10.1029/2002JD003151.

Fiore, A. M., L. W. Horowitz, D. W. Purves, H. Levy II, M. J. Evans, Y. Wang, Q. Li, and R. M. Yantosca (2005), Evaluating the contribution of changes in isoprene emissions to surface ozone trends over the eastern United States, J. Geophys. Res., 110, D12303, doi:10.1029/2004JD005485.

Fiore, A. M., L. W. Horowitz, E. J. Dlugokencky, and J. J. West (2006), Impact of meteorology and emissions on methane trends, 1990-2004, Geophys. Res. Lett., 33, L12809, doi:10.1029/2006GL026199.

Gery, M. W., G. Z. Whitten, J. P. Killus, and M. C. Dodge (1989), A photochemical kinetics mechanism for urban and regional scale computer modeling, J. Geophys. Res., 94, 12,925-12,956, doi:10.1029/ JD094iD10p12925.

Giacopelli, P., K. Ford, C. Espada, and P. B. Shepson (2005), Comparison of the measured and simulated isoprene nitrate distributions above a forest canopy, J. Geophys. Res., 110, D01304, doi:10.1029/2004JD005123.

Giglio, L., I. Csiszar, and C. O. Justice (2006), Global distribution and seasonality of active fires as observed with the Terra and Aqua Moderate Resolution Imaging Spectroradiometer (MODIS) sensors, J. Geophys. Res., 111, G02016, doi:10.1029/2005JG000142.

Guenther, A., et al. (1995), A global model of natural volatile organic compound emissions, J. Geophys. Res., 100, 8873-8892, doi:10.1029/ 94JD02950.

Guenther, A., B. Baugh, G. Brasseur, J. Greenberg, P. Harley, L. Klinger, D. Serca, and L. Vierling (1999), Isoprene emission estimates and uncertainties for the central African EXPRESSO study domain, J. Geophys. Res., 104, 30,625-30,639, doi:10.1029/1999JD900391.

Guenther, A., T. Karl, P. Harley, C. Wiedinmyer, P. I. Palmer, and C. Geron (2006), Estimates of global terrestrial isoprene emissions using MEGAN (Model of Emissions of Gases and Aerosols from Nature), Atmos. Chem. Phys., 6, 3181-3210.

Harrison, D., et al. (2001), Ambient isoprene and monoterpene concentrations in a Greek fir (Abies Borisii-regis) forest: Reconciliation with emissions measurements and effects on measured $\mathrm{OH}$ concentrations, Atmos. Environ., 35, 4699-4711, doi:10.1016/S1352-2310(01)00091-7.

Hauglustaine, D. A., J. Lathière, S. Szopa, and G. A. Folberth (2005), Future tropospheric ozone simulated with a climate-chemistry-biosphere model, Geophys. Res. Lett., 32, L24807, doi:10.1029/2005GL024031.

Heald, C. L., M. J. Wilkinson, R. K. Monson, C. A. Alo, G. Wang, and A. Guenther (2009), Response of isoprene emission to ambient $\mathrm{CO}_{2}$ changes and implications for global budgets, Global Change Biol., in press.

Herman, J. R., P. K. Bhartia, O. Torres, C. Hsu, C. Seftor, and E. Celarier (1997), Global distribution of UV-absorbing aerosols from Nimbus-7/ TOMS data, J. Geophys. Res., 102, 16,911-16,922, doi:10.1029/ 96JD03680.

Hogrefe, C., B. Lynn, K. Civerolo, J.-Y. Ku, J. Rosenthal, C. Rosenzweig, R. Goldberg, S. Gaffin, K. Knowlton, and P. L. Kinney (2004), Simulating changes in regional air pollution over the eastern United States due to changes in global and regional climate and emissions, J. Geophys. Res., 109, D22301, doi:10.1029/2004JD004690.

Horowitz, L. W., J. Liang, G. M. Gardner, and D. J. Jacob (1998), Export of reactive nitrogen from North America during summertime: Sensitivity to hydrocarbon chemistry, J. Geophys. Res., 103(D11), 13,451-13,476, doi:10.1029/97JD03142

Horowitz, L. W., et al. (2003), A global simulation of tropospheric ozone and related tracers: Description and evaluation of MOZART, version 2, J. Geophys. Res., 108(D24), 4784, doi:10.1029/2002JD002853.

Horowitz, L. W., A. M. Fiore, G. P. Milly, R. C. Cohen, A. Perring, P. J. Wooldridge, P. G. Hess, L. K. Emmons, and J.-F. Lamarque (2007), Observational constraints on the chemistry of isoprene nitrates over the eastern United States, J. Geophys. Res., 112, D12S08, doi:10.1029/ 2006JD007747.

Houweling, S., F. Dentener, and J. Lelieveld (1998), The impact of nonmethane hydrocarbon compounds on tropospheric photochemistry, J. Geophys. Res., 103(D9), 10,673-10,696, doi:10.1029/97JD03582.

Ito, A., and J. E. Penner (2005), Historical emissions of carbonaceous aerosols from biomass and fossil fuel burning for the period 1870 2000, Global Biogeochem. Cycles, 19, GB2028, doi:10.1029/ 2004GB002374

Ito, A., S. Sillman, and J. E. Penner (2007a), Effects of additional nonmethane volatile organic compounds, organic nitrates, and direct emissions of oxygenated organic species on global tropospheric chemistry, J. Geophys. Res., 112, D06309, doi:10.1029/2005JD006556.

Ito, A., K. Sudo, H. Akimoto, S. Sillman, and J. E. Penner (2007b), Global modeling analysis of tropospheric ozone and its radiative forcing from biomass burning emissions in the twentieth century, J. Geophys. Res., 112, D24307, doi:10.1029/2007JD008745.

Ito, A., A. Ito, and H. Akimoto (2007c), Seasonal and interannual variations in $\mathrm{CO}$ and $\mathrm{BC}$ emissions from open biomass burning in Southern Africa during 1998-2005, Global Biogeochem. Cycles, 21, GB2011, doi:10.1029/2006GB002848.

Ito, A., et al. (2008), Can we reconcile differences in estimates of carbon fluxes from land-use change and forestry for the 1990s?, Atmos. Chem. Phys., 8, 3291-3310.

Jacob, D. J., J. A. Logan, G. M. Gardner, R. M. Yevich, C. M. Spivakovsky, and S. C. Wofsy (1993), Factors regulating ozone over the United States and its export to the global atmosphere, J. Geophys. Res., 98(D8), 14,817-14,826, doi:10.1029/98JD01224.

Jacob, D. J., et al. (2005), Global budget of methanol: Constraints from atmospheric observations, J. Geophys. Res., 110, D08303, doi:10.1029 2004JD005172.

Johnson, C. E., W. J. Collins, D. S. Stevenson, and R. G. Derwent (1999), Relative roles of climate and emissions changes on future tropospheric oxidant concentrations, J. Geophys. Res., 104(D15), 18,631-18,645, doi:10.1029/1999JD900204.

Karl, T., A. Guenther, R. J. Yokelson, J. Greenberg, M. Potosnak, D. R. Blake, and P. Artaxo (2007), The tropical forest and fire emissions experiment: Emission, chemistry, and transport of biogenic volatile organic compounds in the lower atmosphere over Amazonia, J. Geophys. Res., 112, D18302, doi:10.1029/2007JD008539.

Kuhn, U., et al. (2007), Isoprene and monoterpene fluxes from Central Amazonian rainforest inferred from tower-based and airborne measurements, and implications on the atmospheric chemistry and the local carbon budget, Atmos. Chem. Phys., 7, 2855-2879.

Kunkel, K. E., et al. (2008), Sensitivity of future ozone concentrations in the northeast USA to regional climate change, Mitigation Adaptation Strategies Global Change, 13, 597-606, doi:10.1007/s11027-0079137-y.

Kurpius, M. R., and A. H. Goldstein (2003), Gas-phase chemistry dominates $\mathrm{O}_{3}$ loss to a forest, implying a source of aerosols and hydroxyl radicals to the atmosphere, Geophys. Res. Lett., 30(7), 1371, doi:10.1029/ 2002GL016785.

Lathière, J., D. A. Hauglustaine, N. De Noblet-Ducoudré, G. Krinner, and G. A. Folberth (2005), Past and future changes in biogenic volatile organic compound emissions simulated with a global dynamic vegetation model, Geophys. Res. Lett., 32, L20818, doi:10.1029/2005GL024164.

Lathière, J., D. A. Hauglustaine, A. D. Friend, N. De Noblet-Ducoudré, N. Viovy, and G. A. Folberth (2006), Impact of climate variability and land use changes on global biogenic volatile organic compound emissions, Atmos. Chem. Phys., 6, 2129-2146.

Lelieveld, J., et al. (2002), Global air pollution crossroads over the Mediterranean, Science, 298, 794-799, doi:10.1126/science.1075457.

Lelieveld, J., et al. (2008), Atmospheric oxidation capacity sustained by a tropical forest, Nature, 452, 737-740, doi:10.1038/nature06870.

Li, Q., et al. (2001), A tropospheric ozone maximum over the Middle East, Geophys. Res. Lett., 28(17), 3235-3238, doi:10.1029/2001GL013134.

Liang, J., and M. Z. Jacobson (2000), Effects of subgrid segregation on ozone production efficiency in a chemical model, Atmos. Environ., 34 2975-2982, doi:10.1016/S1352-2310(99)00520-8

Liu, S. C., M. Trainer, F. C. Fehsenfeld, D. D. Parrish, E. J. Williams, D. W. Fahey, G. Hubler, and P. C. Murphy (1987), Ozone production in the rural troposphere and the implications for regional and global ozone distributions, J. Geophys. Res., 92(D4), 4191-4207, doi:10.1029/ JD092iD04p04191.

Liu, X., J. E. Penner, and M. Herzog (2005), Global modeling of aerosol dynamics: Model description, evaluation, and interactions between sulfate and nonsulfate aerosols, J. Geophys. Res., 110, D18206, doi:10.1029/ 2004JD005674.

McKeen, S. A., E.-Y. Hsie, and S. C. Liu (1991), A study of the dependence of rural ozone on ozone precursors in the eastern United States, J. Geophys. Res., 96(D8), 15,377-15,394, doi:10.1029/91JD01282.

McLinden, C., S. Olsen, B. Hannegan, O. Wild, M. Prather, and J. Sundet (2000), Stratospheric ozone in 3-D models: A simple chemistry and the cross-tropopause flux, J. Geophys. Res., 105(D11), 14,653-14,666, doi:10.1029/2000JD900124.

Mortlock, A. M., and R. Van Alstyne (1998), Military, charter, unreported domestic traffic and general aviation: 1976, 1984, 1992, and 2015 emission scenarios, NASA CR-1998-207639, Natl. Aeronaut. and Space Admin., Washington, D. C.

Müller, J.-F., T. Stavrakou, S. Wallens, I. De Smedt, M. Van Roozendael, M. J. Potosnak, J. Rinne, B. Munger, A. Goldstein, and A. B. Guenther (2008), Global isoprene emissions estimated using MEGAN, ECMWF analyses and a detailed canopy environment model, Atmos. Chem. Phys., $8,1329-1341$.

Murazaki, K., and P. Hess (2006), How does climate change contribute to surface ozone change over the United States?, J. Geophys. Res., 111 D05301, doi:10.1029/2005JD005873. 
Murphy, J. G., A. Day, P. A. Cleary, P. J. Wooldridge, and R. C. Cohen (2006), Observations of the diurnal and seasonal trends in nitrogen oxides in the western Sierra Nevada, Atmos. Chem. Phys., 6, 5321-5338.

Olszyna, K. J., M. Luria, and J. F. Meagher (1997), The correlation of temperature and rural ozone levels in southeastern USA, Atmos. Environ., 31, 3011-3022, doi:10.1016/S1352-2310(97)00097-6.

O'Sullivan, D. W., M. Lee, B. C. Noone, and B. G. Heikes (1996), Henry's law constant determinations for hydrogen peroxide, methyl hydroperoxide, hydroxymethyl hydroperoxide, ethyl hydroperoxide, and peroxyacetic acid, J. Phys. Chem., 100, 3241-3247, doi:10.1021/jp951168n.

Palmer, P. I., et al. (2006), Quantifying the seasonal and interannual variability of North American isoprene emissions using satellite observations of the formaldehyde column, J. Geophys. Res., 111, D12315, doi:10.1029/2005JD006689.

Paulot, F., J. D. Crounse, H. G. Kjaergaard, J. H. Kroll, J. H. Seinfeld, and P. O. Wennberg (2009), Isoprene photooxidation: New insights into the production of acids and organic nitrates, Atmos. Chem. Phys., 9, $1479-1501$

Paulson, S. E., and J. H. Seinfeld (1992), Development and evaluation of a photooxidation mechanism for isoprene, J. Geophys. Res., 97(D18), 20,703-20,715.

Pegoraro, E., A. Rey, G. Barron-Gafford, R. Monson, Y. Malhi, and R. Murthy (2005), The interacting effects of elevated atmospheric $\mathrm{CO}_{2}$ concentration, drought and leaf-to-air vapour pressure deficit on ecosystem isoprene fluxes, Oecologia, 146, 120-129, doi:10.1007/ s00442-005-0166-5.

Perring, A. E., et al. (2009), Airborne observations of total $\mathrm{RONO}_{2}$ : New constraints on the yield and lifetime of isoprene nitrates, Atmos. Chem. Phys., 9, 1451-1463.

Pickering, K. E., Y. Wang, W.-K. Tao, C. Price, and J.-F. Müller (1998), Vertical distributions of lightning $\mathrm{NO}_{\mathrm{x}}$ for use in regional and global chemical transport models, J. Geophys. Res., 103(D23), 31,20331,216, doi:10.1029/98JD02651.

Pöschl, U., R. von Kuhlmann, N. Poisson, and P. J. Crutzen (2000), Development and intercomparison of condensed isoprene oxidation mechanisms for global atmospheric modeling, J. Atmos. Chem., 37, 29-52, doi:10.1023/A:1006391009798.

Prather, M., et al. (2003), Fresh air in the 21 st century?, Geophys. Res. Lett., 30(2), 1100, doi:10.1029/2002GL016285.

Racherla, P. N., and P. J. Adams (2006), Sensitivity of global tropospheric ozone and fine particulate matter concentrations to climate change, J. Geophys. Res., 111, D24103, doi:10.1029/2005JD006939.

Racherla, P. N., and P. J. Adams (2008), The response of surface ozone to climate change over the eastern United States, Atmos. Chem. Phys., 8, $871-885$.

Ren, X., et al. (2006), OH, $\mathrm{HO}_{2}$, and $\mathrm{OH}$ reactivity during the PMTACSNY Whiteface Mountain 2002 campaign: Observations and model comparison, J. Geophys. Res., 111, D10S03, doi:10.1029/2005JD006126.

Ren, X., et al. (2008), $\mathrm{HO}_{x}$ chemistry during INTEX-A 2004: Observation, model calculation, and comparison with previous studies, J. Geophys. Res., 113, D05310, doi:10.1029/2007JD009166.

Rosenstiel, T. N., M. J. Potosnak, K. L. Griffin, R. Fall, and R. K. Monson (2003), Increased $\mathrm{CO}_{2}$ uncouples growth from isoprene emission in an agriforest ecosystem, Nature, 421, 256-259, doi:10.1038/nature01312.

Rotman, D. A., et al. (2004), IMPACT, the LLNL 3-D global atmospheric chemical transport model for the combined troposphere and stratosphere: Model description and analysis of ozone and other trace gases, J. Geophys. Res., 109, D04303, doi:10.1029/2002JD003155.

Sander, R., et al. (2006), Chemical kinetics and photochemical data for use in atmospheric studies, Eval. 15, JPL Publ. 06-2, Jet Propul. Lab., Pasadena, Calif

Sanderson, M. G., C. D. Jones, W. J. Collins, C. E. Johnson, and R. G. Derwent (2003), Effect of climate change on isoprene emissions and surface ozone levels, Geophys. Res. Lett., 30(18), 1936, doi:10.1029/ 2003GL017642.

Schubert, S. D., R. B. Rood, and J. Pfaendtner (1993), An assimilated data set for Earth Science applications, Bull. Am. Meteorol. Soc., 74, $2331-$ 2342, doi:10.1175/1520-0477(1993)074<2331:AADFES>2.0.CO;2.

Schwartz, S. E., and W. H. White (1981), Solubility equilibria of the nitrogen oxides and oxyacids in dilute aqueous solution, in Advances in Environmental Science and Engineering, vol. 4, edited by J. R. Pfafflin and E. N. Ziegler, pp. 1-45, Gordon and Breach, New York.

Sillman, S., and P. J. Samson (1995), Impact of temperature on oxidant photochemistry in urban, polluted rural, and remote environments, J. Geophys. Res., 100(D6), 11,497-11,508, doi:10.1029/94JD02146.

Sillman, S., J. A. Logan, and S. C. Wofsy (1990), A regional scale model for ozone in the United States with subgrid representation of urban and power plant plumes, J. Geophys. Res., 95(D5), 5731-5748, doi:10.1029/ JD095iD05p05731.
Singh, H. B., et al. (1998), Latitudinal distribution of reactive nitrogen in the free troposphere over the Pacific Ocean in late winter/early spring, J. Geophys. Res., 103(D21), 28,237-28,247, doi:10.1029/98JD01891.

Singh, H., et al. (2000), Distribution and fate of selected oxygenated organic species in the troposphere and lower stratosphere over the Atlantic, J. Geophys. Res., 105(D3), 3795-3806, doi:10.1029/1999JD900779. Singh, H. B., W. H. Brune, J. H. Crawford, D. J. Jacob, and P. B. Russell (2006), Overview of the summer 2004 Intercontinental Chemical Transport Experiment - North America (INTEX-A), J. Geophys. Res., 111, D24S01, doi:10.1029/2006JD007905.

Sprengnether, M., K. L. Demerjian, N. M. Donahue, and J. G. Anderson (2002), Product analysis of the $\mathrm{OH}$ oxidation of isoprene and 1,3-butadiene in the presence of NO, J. Geophys. Res., 107(D15), 4268, doi:10.1029/2001JD000716.

Steiner, A. L., S. Tonse, R. C. Cohen, A. H. Goldstein, and R. A. Harley (2006), Influence of future climate and emissions on regional air quality in California, J. Geophys. Res., 111, D18303, doi:10.1029/ 2005JD006935.

Stevenson, D. S., C. E. Johnson, W. J. Collins, R. G. Derwent, and J. M. Edwards (2000), Future estimates of tropospheric ozone radiative forcing and methane turnover: The impact of climate change, Geophys. Res. Lett., 27(14), 2073-2076, doi:10.1029/1999GL010887.

Stevenson, D. S., et al. (2006), Multimodel ensemble simulations of present-day and near-future tropospheric ozone, J. Geophys. Res., 111, D08301, doi:10.1029/2005JD006338

Sutkus, D. J., S. L. Baughcum, and D. P. DuBois (2001), Scheduled civil aircraft emission inventories for 1999: Database development and analysis, NASA CR-2001-211216, NASA, Washington, D. C.

Tagaris, E., K. Manomaiphiboon, K.-J. Liao, L. R. Leung, J.-H. Woo, S. He, P. Amar, and A. G. Russell (2007), Impacts of global climate change and emissions on regional ozone and fine particulate matter concentrations over the United States, J. Geophys. Res., 112, D14312, doi:10.1029/2006JD008262.

Tan, D., et al. (2001), $\mathrm{HO}_{x}$ budgets in a deciduous forest: Results from the PROPHET summer 1998 campaign, J. Geophys. Res., 106(D20), 24,407-24,427, doi:10.1029/2001JD900016.

Tao, Z., S. M. Larson, D. J. Wuebbles, A. Williams, and M. Caughey (2003), A summer simulation of biogenic contributions to ground-level ozone over the continental United States, J. Geophys. Res., 108(D14), 4404, doi:10.1029/2002JD002945.

Tao, Z., A. Williams, H.-C. Huang, M. Caughey, and X.-Z. Liang (2007), Sensitivity of U.S. surface ozone to future emissions and climate changes, Geophys. Res. Lett., 34, L08811, doi:10.1029/2007GL029455.

Thornton, J. A., et al. (2002), Ozone production rates as a function of $\mathrm{NO}_{\mathrm{x}}$ abundances and $\mathrm{HO}_{\mathrm{x}}$ production rates in the Nashville urban plume, J. Geophys. Res., 107(D12), 4146, doi:10.1029/2001JD000932.

von Kuhlmann, R., M. G. Lawrence, U. Pöschl, and P. J. Crutzen (2004), Sensitivities in global scale modeling of isoprene, Atmos. Chem. Phys., 4, 1-17.

Wang, Y., D. J. Jacob, and J. A. Logan (1998), Global simulation of tropospheric $\mathrm{O}_{3}-\mathrm{NO}_{\mathrm{x}}$-hydrocarbon chemistry: 1. Model formulation, J. Geophys. Res., 103(D9), 10,713-10,725, doi:10.1029/98JD00158.

Wiedinmyer, C., X. X. Tie, A. Guenther, R. Neilson, and C. Granier (2006), Future changes in biogenic isoprene emissions: How might they affect regional and global atmospheric chemistry?, Earth Interact., 10, 1-19, doi:10.1175/EI174.1.

Wild, O. (2007), Modelling the global tropospheric ozone budget: Exploring the variability in current models, Atmos. Chem. Phys., 7, 2643-2660.

Wild, O., and M. J. Prather (2006), Global tropospheric ozone modeling: Quantifying errors due to grid resolution, J. Geophys. Res., 111, D11305, doi:10.1029/2005JD006605.

Wild, O., P. Pochanart, and H. Akimoto (2004), Trans-Eurasian transport of ozone and its precursors, J. Geophys. Res., 109, D11302, doi:10.1029/ 2003JD004501.

Wu, S., L. J. Mickley, D. J. Jacob, J. A. Logan, R. M. Yantosca, and D. Rind (2007), Why are there large differences between models in global budgets of tropospheric ozone?, J. Geophys. Res., 112, D05302, doi:10.1029/2006JD007801.

Wu, S., L. J. Mickley, E. M. Leibensperger, D. J. Jacob, D. Rind, and D. G. Streets (2008), Effects of 2000-2050 global change on ozone air quality in the United States, J. Geophys. Res., 113, D06302, doi:10.1029/ 2007JD008917.

Yan, X., T. Ohara, and H. Akimoto (2005), Statistical modeling of global soil $\mathrm{NO}_{\mathrm{x}}$ emissions, Global Biogeochem. Cycles, 19, GB3019, doi:10.1029/2004GB002276

Zeng, G., J. A. Pyle, and P. J. Young (2008), Impact of climate change on tropospheric ozone and its global budgets, Atmos. Chem. Phys., 8, 369387 
Zhang, Y., X.-M. Hu, L. R. Leung, and W. I. Gustafson Jr. (2008), Impacts of regional climate change on biogenic emissions and air quality, J. Geophys. Res., 113, D18310, doi:10.1029/2008JD009965.

Zhu, Y. Q., R. Todling, J. Guo, S. E. Cohn, I. M. Navon, and Y. Yang (2003), The GEOS-3 retrospective data assimilation system: The 6-hour lag case, Mon. Weather Rev., 131(9), 2129-2150, doi:10.1175/15200493(2003)131<2129:TGRDAS >2.0.CO;2.

A. Ito (corresponding author), Frontier Research Center for Global Change, Japan Agency for Marine-Earth Science and Technology (JAMSTEC), 3173-25, Showa-machi, Yokohama 236-0001, Japan. (akinorii@jamstec.go.jp)

J. E. Penner and S. Sillman, Department of Atmospheric, Oceanic, and Space Sciences, University of Michigan, Ann Arbor, MI 48109, USA. 